\title{
FUNDAMENTAL LEGAL CONCEPTIONS AS APPLIED IN JUDICIAL REASONING ${ }^{1}$
}

The present discussion, while intended to be intrinsically complete so far as intelligent and convenient perusal is concerned, represents, as originally planned, a continuation of an article which appeared under the same title more than three years ago. ${ }^{2}$ It therefore seems desirable to indicate, in very general form, the scope and purpose of the latter. The main divisions were entitled: Legal Conceptions Contrasted with Non-legal Conceptions; Operative Facts Contrasted with Evidential Facts; and Fundamental Jural Relations Contrasted with One Another. The jural relations analyzed and discussed under the last subtitle were, at the outset, grouped in a convenient "scheme of opposites and correlatives"; 3 and it will greatly facilitate the presentation of the matters to be hereafter considered if that scheme be reproduced at the present point:

\begin{tabular}{|c|c|c|c|c|}
\hline $\begin{array}{c}\text { Jural } \\
\text { Opposites }\end{array}$ & $\left\{\begin{array}{l}\text { right } \\
\text { no-right }\end{array}\right.$ & $\begin{array}{l}\text { privilege } \\
\text { duty }\end{array}$ & $\begin{array}{l}\text { power } \\
\text { disability }\end{array}$ & $\begin{array}{l}\text { immunity } \\
\text { liability }\end{array}$ \\
\hline$\underset{\text { Correlatives }}{\text { Jural }}$ & $\left\{\begin{array}{l}\text { right } \\
\text { duty }\end{array}\right.$ & $\begin{array}{l}\text { privilege } \\
\text { no-right }\end{array}$ & $\begin{array}{l}\text { power } \\
\text { liability }\end{array}$ & $\begin{array}{l}\text { immunity } \\
\text { disability }\end{array}$ \\
\hline
\end{tabular}

The great practical importance of accurate thought and precise expression as regards basic legal ideas and their embodiment in a terminology not çalculated to mislead is not always fully realized-especially by the student not yet far advanced in

${ }^{1}$ Copyright, r9r7, by Wesley Newcomb Hohfeld. The substance of this article, with some expansion and much additional illustrative material from judicial opinions, will form part of a volume to appear shortly under the same title as that here given.

(1913) 23 Yale Law JouRnal, 16, 59. One of the chief purposes of this earlier article was to establish a firm foundation for the analysis and discussion of complex jural interests, or aggregates of jural relations, - the interest of the cestui que trust having been more especially in view. See (1913) 23 Y YLE LAW JourNal, 16-20, and notes. This lastmentioned subject receives some incidental consideration in the pages following; but a more adequate treatment must be reserved for another occasion.

'See (Igr3) 23 Yale LAw JouRNax, I6, 30 ff., where the individual conceptions represented in the scheme are treated at length. 
his legal work; and it is even true that many an experienced lawyer has all too thoughtlessly assumed that those matters usually considered in works on so-called "jurisprudence" are merely "academic" in character and devoid of substantial utility for the practitioner or judge. In order to dissipate, if possible, this fallacious notion-one so demonstrably unfortunate in its consequences as regards all departments of the laws - the eight conceptions represented in the above scheme were analyzed and compared in great detail, the purpose having been not only to exhibit their intrinsic meaning and scope and their relations to

- See Mr. Justice Holmes, The Path of the Law (1897) to HARV. L. REv. 456, 474-475:

"Jurisprudence, as I look at it, is simply law in its most generalized part. Every effort to reduce a case to a rule is an effort of jurisprudence, although the name as used in English is confined to the broadest rules and most fundamental conceptions. One mark of a great lawyer is that he sees the application of the broadest rules. There is a story of a Vermont justice of the peace before whom a suit was brought by one farmer against another for breaking a churn. The justice took time to consider; and then said that he had looked through the statutes and could find nothing about churns, and gave judgment for the defendant. The same state of mind is shown in all our common digests and text-books. Applications of rudimentary rules of contract or tort are tucked away under the head of Railroads or Telegraphs or go to swell treatises on historical subdivisions, such as Shipping or Equity, or are gathered under an arbitrary title which is thought likely to appeal to the practical mind, such as Mercantile Law. If a man goes into law it pays to be a master of it, and to be a master of it means to look straight through all the dramatic incidents and to discern the true basis for prophecy. Therefore, it is well to have an accurate notion of what you mean by law, by a right, by a duty, by malice, intent, and negligence, by ownership, by possession, and so forth. I have in my mind cases in which the highest courts seem to me to have floundered because they had no clear ideas on some of these themes."

The following observations of the same learned judge are also deserving of consideration:

"As long as the matter to be considered is debated in artificial terms there is a danger of being led by a technical definition to apply a certain name, and then to deduce consequences which have no relation to the grounds on which the name was applied." Mr. Justice Holmes in Guy v. Donald (I906) 203 U. S. 399, 406; 27 Sup. Ct. Rep. 63, 64 .

"It is one of the misfortunes of the law that ideas become encysted in phrases and thereafter for a long time cease to provoke further analysis." Mr. Justice Holmes, in Hyde v. United States (IgII) 225 U. S. 347, 391.

Compare the remarks of Lord Kinnear, in Bank of Scotland v. Macleod [I9I4] A. C. 3II, 324. He there endorses Lord Westbury's declaration that "there is not a more fruitful source of error in law than the inac- 
one another, but also to exemplify the methods, both good and bad, by which they are actually applied in judicial reasoning to the solution of concrete problems of litigation. The purpose last indicated must in the present discussion, as in the former one, be the justification for frequent concrete examples of judicial usage, and hence for liberal quotations from apposite judicial opinions. Irstructive examples, whether by way of model or by way of warning, must also be drawn occasionally from the works of well-known legal authors. ${ }^{5}$

In the following pages it is proposed to begin the discussion of certain important classifications which are applicable to each of the eight individual jural conceptions represented in the above scheme. Some of such overspreading classifications consist of the following: relations in personam ("paucital" relations), and relations in rem ("multital" relations); common (or general) relations and special (or particular) relations; consensual relations and constructive relations; primary relations and secondary relations; substantive relations and adjective relations; perfect relations and imperfect relations; concurrent relations (i. e., relations concurrently legal and equitable) and exclusive relations (i. e., relations exclusively equitable).$^{\circ}$ As the buik of our statute and case law becomes greater and greater, these classifications are constantly increasing in their practical importance: not only because of their intrinsic value as mental tools for the compre-

curate use of language," and Lord Mansfield's observation that "nothing in law is so apt to mislead as a metaphor." The learned judge also remarks :

"The fallacy consists in using legal terms in a popular or metaphorical sense and yet affixing to them all the legal consequences which would attach to their use in a strictly technical sense."

See also, as regards confusion of thought resulting from loose or ambiguous legal terms, Field, J., in Morgan v. Louisiana (I876) 93 U. S. 217,223 ; and Peckham, $J$. in Phoenix Ins. Co. v. Tennessee (1895) I6r U. S. 174, 177, I78.

'Owing, however, to limitations of space, it has proved necessary to exclude at this time a large part of the available illustrative material originally intended to be presented.

"For an explanation of the classification of jural relations as "concurrent" and "exclusive" see the writer's article entitled, The Relations between Equity and Law (I9r3) II MicH. L. REv. 537, 553, 569.

See also the article of the writer's friend and colleague, Professor Walter Wheeler Cook, The Alienability of Choses in Action-A Reply to Professor Williston (1917) 30 HARv. L. Rev. 449, 460 ff. 
hending and systematizing of our complex legal materials, but also because of the fact that the opposing ideas and terms involved are at the present time, more than ever before, constituting part of the formal foundation of judicial reasoning and decision. $^{7}$ Owing to limitations of space the following pages will be confined to the first classification above indicated, viz., relations in personam and relations in rem.

The phrases in personam and in rem, in spite of the scope and variety of situations to which they are commonly applied, are more usually assumed by lawyers, judges, and authors to be of unvarying meaning and free of ambiguities calculated to mislead the unwary. The exact opposite is, however, true; and this has occasionally been explicitly emphasized by able judges whose warnings are worthy of notice. Thus, in Tyler $v$. Court of Registration, ${ }^{8}$ Mr. Chief Justice Holmes says, as regards the expression, in rem, that "no phrase has been more misused"; and in the recent case of Hook v. Hoffman, Mr. Justice Franklin, in the course of a scholarly opinion involving the nature of "proceedings in rem," finds it necessary to characterize the expression "jus in rem" as "somewhat obscure and ambiguous." The thoughtful judge last named is, however, kind enough to advise us of the one and only remedy for this difficulty, and prompt to apply that remedy in his own opinion. His words are worthy of quotation:

"It is no more of a solecism to say immovable personal property than it is to say removable fixtures, nor more contradicting than in the division of actions to use the term 'in rem,' when, under the particular state of facts, the action is primarily 'in personam.' In the development of the law it is seldom possible, or, when possible, seldom

"In this sentence the word "formal" must not be ignored; for, in emphasizing for the time being the formal and analytical side of legal problems, the writer would not be thought to underestimate the great importance of other phases of the law, both scientific and practical. He has had occasion elsewhere to discuss more comprehensively the fundamental aspects of the law, including historical, or genetic, jurisprudence; comparative, or eclectic, jurisprudence; formal, or analytical, jurisprudence; critical, or teleological, jurisprudence; legislative, or constructive, jurisprudence; empirical, or functional, jurisprudence- See $A$ Vital School of Jurisprudence and Law, Proc. OF Assw. of Aw. LAw Schools FoR I914, Dp. 76-r39.

(1900) 175 Mass. 7r, 76.

(1915) 16 Ariz. 540, 554 
expedient, to discard established terms. In this connection an observation by Mr. Justice Holmes is peculiarly applicable:

'As long as the matter to be considered is debated in artificial terms, there is danger of being led by a technical definition to apply a certain name, and then to deduce consequences which have no relation to the grounds on which the name was applied.' Guy v. Donald, 203 U. S. 406.

"Instead of rejecting convenient terms because they are ambiguous or not comprehensive, it is better to explain their meanings, or, in the language of old Hobbes, 'to snuff them with distinctions and definitions,' so as to give a better light."10

All this being so, we are forced to recognize at the very outset that the antithetical pair of expressions, in personam and in rem, is constantly being employed as a basis for classifying at least four distinct matters; and that the respective meanings of the expression in personam and the expression in rem are not the same for all of the different situations involved:

First, we have a fundamental classification of primary rights as rights in personam, and rights in rem; Second, there is the well-known classification of all judicial proceedings into proceedings or actions in personam and proceedings or actions in rem; Third, there exists the closely related classification of judgments and decrees (and the corresponding jurisdictions of courts), some being called judgments or decrees in personam, and the others judgments or decrees in rem; Fourth, assuming a judgment or decree in personam to have been obtained as the result of what may be called the "primary stage" of the typical judicial proceeding, the question of its so-called "enforcement"really the "secondary stage" of the judicial proceeding-comes into view ; ${ }^{11}$ and such enforcement is said to be either in per-

\footnotetext{
${ }^{10}$ (I915) I6 Ariz. 540, 558.

1 Compare, as regards the significance and propriety of these terms, "primary stage" and "secondary stage" as applied to a suit in equity or an action at law, Lord Hardwicke, in Penn v. Lord Baltimore (1750) I Ves. 444, 454:

"As to the court's not inforcing the execution of their judgment; if they could not at all, I agree, it would be in vain to make a decree; and that the court cannot inforce their own decree ins rem, in the present case: but that is not an objection against making a decree in the cause; for the strict primary decree in this court
} 
sonam, as in the case of the typical contempt proceeding employed to coerce performance of a decree in equity, or in rem, as in the case of the typical execution sale following upon an ordinary legal judgment in personam. ${ }^{12}$ Anyone who has seriously observed and reflected on the interrelation of ideas and language must realize how words tend to react upon ideas and to hinder or control them. More specifically, it is overwhelmingly clear that the danger of confusion is especially great when the same term or phrase is constantly used to express two or more distinct ideas. Professor Holland, having in mind, as regards this psychological phenomenon, a particular instance not now before us,-viz., the well-known ambiguity of the Latin $j u s$, the German Recht, the Italian diritto, and the French droit, terms used to indicate both "law" as such and "a right" considered as a concrete relation created by law,-does not exaggerate in the least when he says:

"If the expression of widely different ideas by one and the same term resulted only in the necessity for these clumsy periphrases, or obviously inaccurate paraphrases, no great harm would be done; but unfortunately the

as a court of equity is in personam, long before it was settled, whether this court could issue [sic] to put into possession in a suit of lands in England; which was first begun and settled in the time of James I. but ever since done by injunction or writ of assistant to the sheriff: but the court cannot to this day as to lands in Ireland or the plantations. In Lord King's time in the case of Richardson v. Hamilton, Attorney General of Pennsylvania, which was a suit of land and a house in the town of Philadelphia, the court made a decree, though it could not be inforced in rem. In the case of Lord Anglesey of land lying in Ireland, I decreed for distinguishing and settling the parts of the estate, though impossible to inforce that decree in rem, but the party being in England, I could inforce it by process of contempt in personam and sequestration, which is the proper jurisdiction of this court."

It is interesting to observe that Lord Hardwicke speaks of the writ of assistance (under which an equity plaintiff might through the sheriff be put into actual possession of land) as a means by which a court of equity could at times "enforce in rem" the "strict primary decree in personam."

${ }^{12}$ For an able and searching discussion of proceedings in personam and proceedings in rem, see the series of articles by Professor Walter Wheeler Cook entitled, The Powers of Courts of Equity (I915) I5 CoL. L. REv. 37, 106, 228.

See also the present writer's article The Relations between Equity and Law (1913) II MICH. L. REv. 537, passin. 
identity of terms seems irresistibly to suggest an identity between the ideas which are expressed by them."13

No doubt this psychological and linguistic principle-what might be called "the principle of linguistic contamination"explains why certain well-known legal authors have assumed, with unfortunate effect on their reasoning and argument, that the contrasted pairs of terms in personam and in rem have the same intrinsic meaning in each of the four cases above mentioned, and therefore represent throughout a precisely similar basis of classification; also that there is some formal and symmetrical interdependence between the four classifications presented,-e. g., that primary rights in rem are such as may be "enforced," or vindicated, by proceedings and judgments in rem, or, similarly, that primary rights in personam are such as can be "enforced," or vindicated, only by actions or proceedings in personam. At a later point some of these problems and fallacies will receive incidental treatment in connection with the main thread of the discussion, and it will thus be possible to give more concrete specifications and examples. The chief purpose of the following pages is, however, to discuss, directly and exhaustively, only the first of the four general classifications above outlined, i. e., rights (or claims), privileges, powers, and immunities in personam and rights (or claims), privileges, powers, and immunities in rem. Substituting what the writer ventures to suggest as equivalent and more satisfactory terms for the phrases in personam and in rem, we shall have to deal seriatim with eight classifications, as follows: I. paucital rights (or claims) and multital rights (or claims); 2. "paucital privileges and multital

${ }^{13}$ Holland, Jurisp. (roth ed., Ig06) pp. 80-8I.

Compare Austin, Jurisp. (5th ed., I885) Vol. I, pp. 285-286, note, referring to the same ambiguity as Holland, and adding:

"Since the strongest and wariest minds are often ensnared by ambiguous words, their (the Germans') confusion of those disparate objects is a venial error."

Compare also Austin, Jurisp., Vol. I, p. 322, note:

"In the language of English jurisprudence, facts or events which are contracts quasi or $u t i$, are styled implied contracts, or contracts which the law implies: that is to say, contracts quasi or $u t i$, and genuine though tacit contracts, are denoted by a common name, or by names nearly alike. And, consequently, contracts, quasi or $u t i$, and implied or tacit contracts, are commonly or frequently confounded by English lawyers. See, in particular, Sir William Blackstone's Commentaries, B. II. Ch. 30. and B. III. Ch. 9." 
privileges; 3 . paucital powers and multital powers; 4 . paucital immunities and multital immunities; 5 . paucital no-rights and multital no-rights; 6 . paucital duties and multital duties; 7 . paucital disabilities and multital disabilities; 8. paucital liabilities and multital liabilities. Each of these eight definite classifications must, for the sake of clearness, receive somewhat separate treatment. Owing, however, to limitations of space, the present article will deal chiefly with the first subdivision, i. e., paucital rights, or claims, and multital rights, or claims.

As more fully shown in the former article, the word "right" is used generically and indiscriminately to denote any sort of legal advantage, whether claim, privilege, power, or immunity. ${ }^{14}$ In its narrowest sense, however, the term is used as the correlative of duty;" and, to convey this meaning, the synonym "claim" seems the best.18 In what follows, therefore, the term "right" will be used solely in that very limited sense according to which it is the correlative of duty. It is hoped that the meaning and importance of this needful discrimination may gain in concreteness and clearness as further details and examples come into view.

"For judicial opinions recognizing the broad and generic significance of this term when loosely used, see the authorities discussed in (r913) 23 YAIE LAW JouRnar, I6, $30 \mathrm{ff}$.

Compare also, to similar effect, Slater, J., in Shaw v. Proffitt (rgro) 57 Or. r92, 20r:

"It is strenuously urged by defendant's counsel that, under the pleadings in this case, plaintiff stands on a bare parol license, which he claims to have obtained from the defendant and his predecessors in interest and that, therefore, plaintiff is precluded from obtaining the full effect of his evidence. We do not agree with such restricted interpretation of the language found in the complaint. It is averred that plaintiff obtained the 'right' as well as the 'consent, permission and license of defendant and his predecessors.' The word 'right' denotes, among other things, 'property,' 'interest,' 'power,' 'prerogative,' 'immunity,' and 'privilege,' and in law is most frequently applied to property in its restricted sense."

${ }^{13}$ See (1913) 23 YaLe LaW Journax, 16, 3I-32.

${ }^{16}$ In this connection, the language of Mr. Justice Stayton, though not recommended for precision, may well be compared:

" $A$ right has been well defined to be a well-founded claim, and a well-founded claim means nothing more nor less than a claim recognized or secured by law.

"Rights which pertain to persons, other than such as are termed natural rights, are essentially the creatures of municipal law, written or unwritten, and it must necessarily be held that a right, in a legal sense, exists, when in consequence of given facts the law declares that one person is entitled to enforce against another a claim ...." Mellinger $v$. City of Huston (I887) 68 Tex. 37,$45 ; 3$ S. W. 249,253 . 
It is necessary at this point to venture a preliminary explanation of the division or classification now before us-confessing at once that it represents a departure from accepted modes of statement or definition on the part of learned authors and judges. It will then remain for the more detailed discussion and argument to show, if possible, that the currently received explanations are not only essentially faulty as regards analysis but also seriously misleading for the very practical purpose of solving legal problems as swiftly and accurately as possible.

A paucital right, or claim, (right in personam) is either a unique right residing in a person (or group of persons) and availing against a single person (or single group of persons) ${ }^{17}$; or else it is one of a few fundamentally similar, yet separate, rights availing respectively against a few definite persons. ${ }^{18} \mathrm{~A}$ multital right, or claim, (right in rem) is always one of a large class of fundamentally similar yet separate rights, actual and potential, ${ }^{19}$ residing in a single person (or single group of persons) but availing respectively against persons constituting a very large and indefinite class of people. ${ }^{20}$

Probably all would agree substantially on the meaning and significance of a right in personam, as just explained; and it is easy to give a few preliminary examples: If $B$ owes $A$ a thousand dollars, $A$ has an affirmative right in personam, or paucital right, that $B$ shall transfer to A the legal ownership of that amount of money. If, to put a contrasting situation, $A$ already

${ }^{17}$ The words "group of persons" are intended to cover cases of so-called "joint" rights and duties.

${ }^{18}$ While the word "paucital" is suggested as the generic term to cover all rights in personom, the word "unital" would be available to denote that particular kind of right in personam that is "unique" and "uncompanioned."

${ }^{10}$ The reasons for including the words, "actual and potential" must be discussed at a later time, after a general consideration of the distinction between "actual" and "potential" jural relations.

${ }^{x}$ It is not infrequently thought that the word "general" is both appropriate and available to denote those rights, or claims, that are here called "multital." See, e. g., Markby, Elements of Law (6th ed., I905) sec. 165. It is submitted, however, that according to the best usage the term "general," as applied to a jural relation, indicates that the latter is one of a large class of similar relations residing respectively in many persons, i. e., people in general. For example, any duty correlating with a multital right would be a general, or common, duty. The right of person not to be struck by another is both multital and general.

This matter will receive more complete consideration at a later time. 
has title to one thousand dollars, his rights against others in relation thereto are multital rights, or rights in rem. In the one case the money is owed to $\mathrm{A}$; in the other case it is owned by A. ${ }^{21}$ If $Y$ has contracted to work for $X$ during the ensuing six months, $\mathrm{X}$ has an affirmative right in personam that $\mathrm{Y}$ shall render such service, as agreed. Similarly as regards all other contractual or quasi-contractual rights of this character. On the other hand, there may occasionally be rights in personam of a negative tenor or content. Thus if $\mathrm{K}$, a distinguished opera singer, contracts with $\mathrm{J}$ that the former will not for the next three months sing at any rival opera house, $J$ has a negative right in personam against $\mathrm{K}$; and the latter is under a correlative negative duty. In this, as in other cases of rights in the sense of claims, the right of $J$ is but one phase of the total relation between $J$ and $K$, and the duty of $K$ is another phase of the same relation,-that is, the whole "right-duty" relation may be viewed from different angles.

In contrast to these examples are those relating to rights, or claims, in rem-i. e., multital rights. If $\mathrm{A}$ owns and occupies Whiteacre, not only $B$ but also a great many other personsnot necessarily all persons ${ }^{22}$-are under a duty, e. g., not to enter on A's land. A's right against $B$ is a multital right, or right in rem, for it is simply one of A's class of similar, though separate, rights, actual and potential, against very many persons. The same points apply as regards $A$ 's right that $B$ shall not commit a battery on him, $A$ 's right that $B$ shall not alienate the affections of A's wife, and A's right that $B$ shall not manufacture a certain article as to which $A$ has a so-called patent.

\footnotetext{
${ }^{2}$ Compare Pollock and Maitland, History of English Law (2d ed., I905) Vol. II, p. 178.

$=$ It is sometimes assumed that rights in rem (considered collectively) are such only as avail against absolutely all persons,-an idea fostered in part by the frequently-used expression "against all the world." See, e. g., Langdell, Summary of Equity Pleading (2d ed., I883) sec. I84; Langdell, Brief Survey of Equity Jurisdiction (I887) I HARV. L. REv. 60; Hart, The Place of Trusts in Jurisprudence (19I2) 28 LAW QUART. REv. 290, 296; Terry, The Arrangement of the Law (r917) I7 CoL. L. REv. 365,376 . This notion is not warranted according to general usage. $\mathrm{If}_{\mathrm{z}}$ for example, $A$, the owner of Blackacre, has given his friends $C$ and $D$, "leave and license" to enter, $A$ has no rights against $C$-and $D$ that they shall not enter; but he has such rights against persons in general; and they are elearly to be classified as being "multital" or "in rem."

For further phases of this matter, see ante, p. 718 n. 19; post, pp. 754-760.
} 
Further examples of such negative $e^{23}$ multital rights will readily occur to the reader. Other important instances will require detailed consideration from time to time.

In spite of the formal and abstract explanations already given, and in spite of the concrete examples added for merely preliminary purposes, the effort to give an incisive and comprehensive appreciation of the conceptual and linguistic difficulties and dangers involved in the expressions under consideration would doubtless fail, at least as regards the inexperienced student, unless considerably more were done by way of direct discussion of common errors. That is to say, it seems necessary to show very concretely and definitely how, because of the unfortunate terminology involved, the expression "right in rem" is all too frequently misconceived, and meanings attributed to it that could not fail to blur and befog legal thought and argument. Some of these loose and misleading usages will now be considered in detail, it being hoped that the more learned reader will remember that this discussion, being intended for the assistance of law school students more than for any other class of persons, is made more detailed and elementary than would otherwise be necessary.

(a) A right in remi is not a right "against a thing": In Hook v. Hoffman ${ }^{24}$ we are told by Mr. Justice Franklin, in hopeful vein, that "the somewhat obscure and ambiguous expression 'jus in rem,' when standing by itself, catches a borrowed clearness from the expression 'jus in personam,' to which it is opposed."25 This is laudable optimism! It cannot, however, be shared by one who has, in the course of many years, observed not only the ways and tendencies of many hundreds of intelligent students, but also the not unnatural slips of the more learned. Any person, be he student or lawyer, unless he has contemplated the matter analytically and assiduously, or has been put on notice by books or other means, is likely, first, to translate right in

\footnotetext{
2 As indicated by the examples given, multital rights are always constructive rather than consensual; that is, they and their correlating duties arise independently of even an approximate expression of intention on the part of those concerned. This explains, no doubt, why most, if not all, of such duties are negative in character: it is just and politic to spread such merely negative duties broadcast; whereas precisely the opposite would be true in the case of most kinds of affirmative duties.

${ }^{24}$ (19r5) I6 Ariz. 540, 555 .

${ }^{25}$ Compare, for precisely similar language, Austin, Jurisp. (5th ed., 1885) Vol. II, p. 957.
} 
personam as a right against a person; and then he is almost sure to interpret right in rem, naturally and symmetrically as he thinks, as a right against a thing. Assuming that the division represented by in personam and in rem is intended to be mutually exclusive, it is plausible enough to assume also that if a right in personam is simply a right against a person, a right in rem must be a right that is not against a person, but against a thing. That is, the expression right in personam, standing alone, seems to encourage the impression that there must be rights that are not against persons. Then, of course, such a supposed, though erroneous, contrast is further encouraged by the prima facie literal meaning of the Latin phrase in rem, considered per se; for it cannot be assumed that the average person is acquainted with the peculiar history and special meaning of that phrase. Such a notion of rights in rem is, as already intimated, crude and fallacious; and it can but serve as a stumbling-block to clear thinking and exact expression. A man may indeed sustain close and beneficial physical relations to a given physical thing: he may physically control and use such thing, and he may physically exclude others from any similar control or enjoyment. But, obviously, such purely physical relations could as well exist quite apart from, or occasionally in spite of, the law of organized society: physical relations are wholly distinct from jural relations. ${ }^{28}$ The latter take significance from the law; and, since the purpose of the law is to regulate the conduct of human beings, all jural relations must, in order to be clear and direct in their meaning, be predicated of such human beings. The words of able judges may be quoted as showing their realization of the practical importance of the point now being emphasized:

I900, Mr. Chief Justice Holmes, in Tyler v. Court of Registration: 27

"All proceedings, like all rights, are really against persons. Whether they are proceedings or rights in rem depends on the number of persons affected."28

${ }^{26}$ As to the prevalent and unfortunate tendency to confuse legal and non-legal conceptions, see the more general discussion in (1913) 23 YaLE LAW Journal, 16, 20 ff.; see also post, p. 725, n. 34 ; and p. 755, n. 90.

${ }^{27}$ (1900) 175 Mass. 71, 76.

* Compare also the following from Mr. Justice Holmes' opinion :

"It is true as an historical fact that these symbols are used in admiralty proceedings, and also, again merely as an historical fact, that the proceedings in rem have been confined to cases where 
I905, Mr. Justice Markby, Elements of Low:29

"If we attempt to translate the phrase [in rem] literally, and get it into our heads that $a$ thing, because rights exist in respect of it, becomes a sort of juristical person, and liable to duties, we shall get into endless confusion."3o

What is here insisted on,-i. e., that all rights in rem are against persons, - is not to be regarded merely as a matter of

certain classes of claims, although of very divers sorts,-for indemnification for injury, for wages, for salvage, etc.,-are to be asserted. But a ship is not a person. It cannot do a wrong or make a contract. To say that a ship has committed a tort is merely a shorthand way of saying that you have decided to deal with it as if it had committed one, because some man has committed one in fact. There is no a priori reason why any other claim should not be enforced in the same way. If a claim for a wrong committed by a master may be enforced against all interests in the vessel, there is no juridical objection to a claim of title being enforced in the same way. The fact that it is not so enforced under existing practice affords no test of the powers of the Legislature. The contrary view would indicate that you really believed the fiction that a vessel had an independent personality as a fact behind the law." (1900) I75 Mass. 71, 77.

20 (6th ed., I905) sec. 165 .

${ }^{20}$ To say that all rights, or claims, must be against persons is, of course, simply another way of asserting that all duties must be predicated of persons. The latter is, in truth, no less obvious than the proposition that all rights must be predicated of persons.

Compare Mr. Justice Markby, in his Elements of Law (6th ed., 1905) sec. 163 :

"The chief, in my opinion the only, use of a division of law into the law of persons and the law of things is as a convenient arrangement of topics in a treatise or a code. As used for this purpose I shall speak of it hereafter. But by slightly changing the terms in which this classification is expressed, Blackstone has introduced an important error, which it is desirable to notice here. He speaks not of the law of persons and of the law of things, but of rights of persons and of rights of things. Rights of persons there are undoubtedly; for all rights are such. There may be also rights over things, and rights over persons; but rights of, that is, belonging to, things, as opposed to rights of, that is, belonging to, persons, there cannot be."

Compare also Mr. Justice Henshaw in Western Indemnity Co. $v$. Pillsbury (I915) 170 Cal. 686, 719:

"Again it is said that it is thought expedient that the loss by injuries to workmen should be borne by the industries and not by the men. But this is only a euphemism which obscures the facts and darkens reason. It is like other happy catch-phrases that deceive the mind by pleasing the ear. We have many such. 'Putting the rights of property before the rights of men', is oneas though property apart from those of its human owner, ever did or could have any rights. So that the rights of property are absolutely the rights of men." 
taste or preference for one out of several equally possible forms of statement or definition. Logical consistency seems to demand such a conception, and nothing less than that. Some concrete examples may serve to make this plain. Suppose that $A$ is the owner of Blackacre and $\mathrm{X}$ is the owner of Whiteacre. Let it be assumed, further, that, in consideration of $\$ 100$ actually paid by $A$ to $B,^{31}$ the latter agrees with $A$ never to enter on $X$ 's land, Whiteacre. It is clear that A's right against $B$ concerning Whiteacre is a right in personam, or paucital right; for $A$ has no similar and separate rights concerning Whiteacre availing respectively against other persons in general. On the other hand, A's right against $\mathrm{B}$ concerning Blackacre is obviously a right in rem, or multital right; for it is but one of a very large number of fundamentally similar (though separate) rights which $A$ has respectively against $B, C, D, E, F$, and a great many other persons. It must now be evident, also, that $A$ 's Blackacre right against $\mathrm{B}$ is, intrinsically considered, of the same general character as A's Whiteacre right against $B$. The Blackacre right differs, so to say, only extrinsically, that is, in having many fundamentally similar, though distinct, rights as its "companions." So, in general, we might say that a right in personam is one having few, if any, "companions"; whereas a right in rem always has many such "companions."

If, then, the Whiteacre right, being a right in personam, is recognized as a right against a person, must not the Blackacre right also, being, point for point, intrinsically of the same general nature, be conceded to be a right against a person? If not that, what is it? How can it be apprehended, or described, or delimited at all?

If it be said that, as regards Blackacre, $\mathrm{A}$ has besides his rights, or claims, against $\mathrm{B}, \mathrm{C}, \mathrm{D}, \mathrm{E}$, and others, various legal privileges of controlling and using the land, and that these exist "to, over, or against" the land, one answer might be that as regards Whiteacre also $\mathrm{A}$ has similar privileges against $\mathrm{B}, \mathrm{C}, \mathrm{D}, \mathrm{E}$ and all others excepting $X$, the true owner. But the really relevant and paramount reply at this point is that we are now dealing only with multital rights, or claims, and not with multital privileges. The latter will require attention in a later part of the discussion. ${ }^{82}$

" The consideration being actually paid to B, the validity of B's promise to $A$ is, of course, not subject to question merely because $B$ was already under a similar duty to $\mathrm{X}$.

See post, pp. 745-752. 
It may, however, even at this point be incidentally noticed that the general tendency to "confuse" or "blend" legal privileges with legal rights, or claims, has doubtless contributed greatly to the hazy conception of a right in rem as a right to, over, or against a thing.

For the reasons already given the following passages from legal treatises and judicial opinions seem open to question in one or more particulars:

I874, Mr. Stephen Martin Leake, Law of Property in Land:

"Jurisprudence distinguishes Rights, using the term in the strict legal meaning, into the two classes of Rights to Things and Rights against Persons, familiarly known in the civil law by the terms jura in rem and jura in personam.

"Rights to things, jura in rem, have for their subject. some material thing, as land or goods, which the owner may use or dispose of in any manner he pleases within the limits prescribed by the terms of his right. A right of this kind imports in all persons generally the correlative negative duty of abstaining from any interference with the exercise of it by the owner; and by enforcing this duty the law protects and establishes the right. But a right of this kind does not import any positive duty in any determinute person, or require any act or intervention of such person for its exercise and enjoyment.

"Rights against persons, jura in personam, on the other hand, have for their subject an act or performance of some certain determinate person, as the payment of money, the delivery of goods and the like. A right of this kind imports the correlative positive legal duty in the determinate person to act in the manner prescribed. It depends for its exercise or enjoyment upon the performance of that duty, and is secured by the legal remedies provided for a breach of performance. . .

"Rights to things, jura in rem, vary and are distinguished according to the things or material subjects in the use or disposal of which the right consists."

The learned author, whose work is well known to law students and highly valued for its general clearness and accuracy, has been unfortunate in treating "in rem" as if it meant "to a thing"; and it would seem that he was influenced to do this, partly at least, as a result of confusing legal privileges and legal rights. More than that, this first error has led to an additional

\footnotetext{
* Law of Property in Land (Ist ed., 1874) pp: I, 2.
} 
one: that of conveying the impression that all rights in rem (multital rights), in order to be such, must relate to a material thing. Such a limitation would exclude not only many rights in rem, or multital rights, relating to persons, but also those constituting elements of patent interests, copyright interests, etc. Finally the learned author falls into the error of asserting that all rights in personam are affirmative in character; whereas they may occasionally be negative, as heretofore seen.

I9I6, Professor Joseph Henry Beale, Treatise on Conflict of Laws:

"The nature of rights.-The primary purpose of law being the creation of rights, and the chief task of the Conflict of Laws to determine the place where a right arose and the law that created it, a more careful study of the nature of rights is of course desirable before the examination of actual cases of conflict is begun. . . .

"Since we are fortunate enough to have different words for these ideas [law and rights] it is all the more necessary that we should fully understand each of them.

" $A$ right may be defined as a legally recognized interest in, to, or against a person or a thing." ${ }^{34}$

\footnotetext{
"Beale, Treatise on Conflict of Laws (I916) sec. 139. All will agree with Professor Beale that, for accurate thinking and correct results in the conflict of laws, it is of vital importance to have sound and consistent conceptions of legal rights and other jural relations; and it is evident that, pursuant to this idea, much of the learned author's reasoning and very many of his arguments and conclusions on specific problems in the conflict of laws have, very naturally, been directly based on his "preliminary survey" of "rights" and on his supposed distinction between what he calls "static rights" and what he calls "dynamic rights."

Yet it may be doubted whether Professor Beale has made clear and consistent his conception of a so-called "static right," as "a legally recognized interest in, to, or against a person or a thing"; and thus one is forced the more to question the validity of many of his arguments and conclusions in the closely related fields of jurisprudence and conflict of lawes.

At one time the "static right" seems to be a purely factual "interest" existing independently of law; at another time a relation "created by law." The former idea is singgested when the learned author refers to Gareis's definition of "interests." This appears very clearly not only from the intrinsic meaning of Gareis's language as quoted by Professor Beale, but also from certain introductory words which are to be found in Gareis's original work: "Interests, considered as facts, arise directly from egoism, and are nothing other than subjectively perceived relations," etc. See Gareis, Systematic Survey (Kocourek's translation) p. 3r. Indeed, Professor Beale himself, in the very definition quoted in the text of the
} 
I903, Mr. Herbert Thorndyke Tiffany, Modern Law of Real Property:

"Powers of attorney, by which one person is nominated as an agent to make a transfer or do some other act in the name and stead of the principal, are sometimes spoken of as common-law powers. Such an authority, however, while it did exist as common law, is entirely different from the powers here considered (i. e., powers of appointment), since it is merely an agency in the person to whom the power is given, authorizing him to execute an instrument of conveyance or to do some other act in the place and stead of his principal, the title passing, not by the power of attorney, but by the conveyance subsequently made, which is regarded as made by the principal. $A$ pozerer of attorney creates merely a contractual relation,-rights in personam,-as does any other contract of agency; while a pozer, such as zere here treat of, involving dominion over land to a greater or less extent, creates in the person to whom the power is given rights in rem of a proprietary character., 35

The exact meaning of the learned author is not evident; but

present article, defines "a right" as an "interest," not as some legal relation protecting the interest: there is a very obvious difference-and one vitally important for the solution of problems in the conflict of lawsbetween a mere factual interest and its legal recognition (legal claims, privileges, etc.).

In sec. I4I, however, we find the following:

"A static right, or as it is commonly called a vested interest, is a legally protected interest in a person or thing. Such an interest is one which continues indefinitely, and protection of it therefore requires a right which, like the interest it protects, has the character of permanence. Accordingly a static right remains in existence until either the subject of the interest ceases to exist or the law itself by a special act puts an end to the right."

In this passage we are told first, that a "static right" is an interest; second, that the "right" is something other than "the interest it protects"; third, that "a static right remains in existence until . . . . the law itself . . . . puts an end to the right."

A similar sudden and difficult shift seems to occur in sec. 142. Thus:

"A static right, as has been seen, is the interest of a person in a thing or in a person; the right is created by law, and once created it is permanent, that is, it persists until the proper law puts an end to it. The law that creates it, as will be seen, also provides for its preservation, by creating a hedge of protecting rights about it; rights of the owner or possessor to have it free from interference or destruction. . . . It is to be regarded as a legal entity quite apart from the particular protection with which it may be endued
by law."

* Modern Law of Real Property (1903) sec. 273. 
it seems clear that the power of an agent to convey Whiteacre is not intrinsically different, so long as it endures, from a power to convey Whiteacre in exercise of a so-called power of appointment. It is true that the agent is subject to a liability of having his power "revoked" or divested by the principal, whereas the power of appointment is subject to no similar liability at the hands of anyone. But this difference, conceding its great importance, is, of course, not accurately expressed by asserting that the power of attorney creates rights in personam, and the power of appointment "creates in the person to whom the power is given rights in rem of a proprietary character." In truth the creation of a power of agency does not necessarily involve any contract rights against the principal or any one else. ${ }^{36}$ The fact seems to be that the greater "staying" quality of the power of appointment (as compared with the power of agency) has suggested to the author greater "adhesiveness" or "thingness," and hence caused the inappropriate terms now under review. Further critical consideration of the last-quoted passage will be desirable in connection with the subject of immunities in personam and immunities in rem.

I828, Sir Thomas Plumer, M.R., in Dearle v. Hall:

"They say, that they were not bound to give notice to the trustees; for that notice does not form part of the necessary conveyance of an equitable interest. I admit, that, if you mean to rely on contract with the individual, you do not need to give notice; from the moment of the contract, he, with whom you are dealing, is personally bound. But if you mean to go further, and to make your right attach upon the thing which is the subject of the contract, it is necessary to give notice; and, unless notice is given, you do not do that which is essential in all cases of transfer of personal property. . . . Notice, then, is necessary to perfect the title,- - to give a complete right in rem, and not merely a right as against him who conveys his interest." ${ }^{37}$

This passage from Dearle $v$. Hall will require further treatment in connection with the subject of immunities in personam and immunities in rem.

I857, Mr. Justice Cutting, in Redington v. Frye:

"But a sub-contractor has no claim against the ozwner of the property-his claim is only against the property

${ }^{26}$ See Huffcut, Agency (2d ed., Igor) sec. Io.

" (1828) 3 Russ. I, 22, 24. 
(in rem), and the person and property of his employer (in personam)."38

The preceding quotations from legal treatises and judicial opinions have been presented, as is evident, for the purpose of exemplifying the less careful and exact use of terms that we sometimes find, and for the further purpose of indicating the confusion of thought that is likely to result in such cases. Over against these will now be considered various passages from legal treatises and judicial opinions exemplifying more precise modes of thought and expression. It is desirable to begin with Austin; for his work on Jurisprudence was the first to give prominence to the terms right in rem and right in personam among Englishspeaking lawyers and authors, and his language has become classical in its importance:

1832, Professor John Austin, Lectures on Jurisprudence or The Philosophy of Positive Law:

"The distinction between Rights which I shall presently endeavour to explain, is that all-pervading and important distinction which has been assumed by the Roman Institutional Writers as the main groundwork of their arrangement: namely, the distinction between rights in rem and rights in personam; or rights which avail against persons generally or universally, and rights which avail exclusively against certain or determinate persons. ${ }^{89}$

(1857) 43 Me. 578, 587.

"The pair of terms, "jus in personam" and " $j u s$ in rem" as contrasted with the pair of terms, "actio in personam" and "actio in rem," was not in general use among the Roman jurists. Compare Clark, History of Roman Law: Jurisprudence, Vol. II, p. 7II: "Jus in rem and Jus in re in Roman Law. The former of these expressions is very little used by the Roman Jurists, but, in the few passages in which it occurs, res clearly means the thing itself as distinguished e. g. from its value. (See Ulpian, Dig. 32. 20. Nullum quidem jus in ipsam rem habere, sed actionem de pretio. Cf. Goudsmit, 247 n.)"

It is clear, therefore, that the "all-pervading and important" Roman law distinction to which Austin refers was that represented by obligatio and dominium. Compare Austin, Jurisp. (5th ed., r885) Vol. I, p. 383: "By jus in rem and jus in personam, the authors of those terms intended to indicate this broad and simple distinction; which the Roman lawyers also marked by the words dominium and obligatio-terms the distinction between which was the groundwork of all their attempts to arrange rights and duties in an accurate or scientific manner." Also Austin, Jurisp., Vol. II, p. 773: "The first great distinction among primary rights has been very fully explained in a preceding part of this Course. I allude to the 
"The terms 'jus in rem' and 'jus in personam' were devised by the Civilians of the Middle Ages, or arose in times still more recent. . .

"The phrase in rem denotes the compass, and not the subject of the right. It denotes that the right in question avails against persons generally; and not that the right in question is a right over a thing. For, as I shall show hereafter, many of the rights, which are jura or rights in rem, are either rights over, or to, persons, or have no subject (person or thing).

"The phrase in personam is an elliptical or abridged expression for 'in personam certam sive determinatam.' Like the phrase in rem, it denotes the compass of the right. It denotes that the right avails exclusively against a determinate person, or against determinate persons." 40

Additional explanations of ideas and terms and further instructive examples of usage are to be found in the following utterances of able judges:

I87r, Mr. Justice Markby, Elements of Law:

"The term 'right in rem' is a very peculiar one; translated literally it would mean nothing. The use of it in conjunction with the term 'in personam' as the basis of a classification of actions in the Roman law has been explained above, and its meaning will be further illustrated by two passages in the Digest of Justinian. In Book iv. tit. 2. sec. 9, the rule of law is referred tothat what is done under the influence of fear should not be binding: and commenting on this it is remarked, that the lawgiver speaks here generally and 'in rem,' and does not specify any particular kind of persons who cause the fear; and that therefore the rule of law applies, whoever the person may be. Again, in Book xliv. tit. 4 . sec. 2 , it is laid down that, in what we should call a plea of fraud, it must be specially stated whose fraud is complained of, 'and not in rem.' On the other hand, it is pointed out that, if it is shown whose fraud is complained of, it is sufficient; and it need not be said whom the fraud was intended to injure; for (says the author of the Digest) the allegation that the transaction is void, by reason of the fraud of the person named, is made 'in rem.' In all these three cases 'in rem' is used as an adverb, and I think we should express as nearly as

distinction between dominia and obligationes, as they were called by the classical jurists; between jura in rem and jura in personam, as they have been styled by modern Civilians."

o Jurisp. (5th ed., 1885) Vol. I, pp. 369, 370. 
possible its exact equivalent, if we substituted for it the English word 'generally.' In the phrase 'right in rem' it is used as an adjective, and the equivalent English expression would be a 'general right'; but a more explicit phrase is a 'right availing against the world at large': and if this, which is the true meaning of the phrase 'right in rem,' be carefully remembered, no mistake need occur." 41

I883, Mr. Justice Mulkey, in W., St. L. \& P. Ry. Co. v. Shacklet:

"One of the primary rights of the citizen, sanctioned by the positive law of the State, is security to life and limb, and indemnity against personal injuries occasioned by the negligence, fraud or violence of others. This is a right which avails against all persons whomsoever, and is distinguished from a right which avails against $a$ particular individual or a determinate class of persons. The former is called a right in rem, the latter a right in personam. The former class of rights exists independently of contract; the latter frequently arises out of contract. . . .

"So in the present case, appellee's intestate had a right in rem, or a general right, which entitled him, if free from fault himself, to be protected and indemnified against injuries resulting from the negligence of all persons whomsoever, including the appellant. . . ."142

I886, Mr. Justice Holmes, in Hogan v. Barry:

"There is no doubt that an easement may be created by words sounding in covenant. Bronson v. Coffin, I08 Mass. I75, I80. If the seeming covenant is for a present enjoyment of a nature recognized by the law as capable of being conveyed and made an easement,-capable, that is to say, of being treated as a jus in rem, and as not merely the subject of a personal undertaking, - and if the deed discloses that the covenant is for the benefit of adjoining land conveyed at the same time, the covenant must be construed as a grant, and, as is said in Plowden, 308, 'the phrase of speech amounts to the effect to vest a present property in you.' An easement will be created and attached to the land conveyed, and will pass with it to assigns, whether mentioned in the grant or not."

"Elements of Law (6th ed., I905) sec. I65.

( 1883 ) 105 III. $364,379$.

(1886) 143 Mass. 538. 
Ig03, Mr. Justice Holmes, in International Postal Supply Co. ข. Bruce:

"As the United States could not be made a party the suit failed. In the case at bar the United States is not the owner of the machines, it is true, but it is a lessee in possession, for a term which has not expired. It has a property, a right in rem, in the machines, which, though less extensive than absolute ownership, has the same incident of a right to use them while it lasts." 44

r904, Mr. Justice Holmes, in Baltimore Shipbuilding Co. v. Baltimore:

"In the next place, as to the interest of the United States in the land. This is a mere condition subsequent. There is no easement or present right in rem. The obligation to keep up the dock and to allow the United States to use it carries active duties and is purely personal. ... The United States has no present right to the land, but merely a personal claim against the corporation, reinforced by a condition." 45

I905, Mr. Justice Holmes, in Muhlker v. Harlem R. R. Co.:

"What the plaintiff claims is really broperty, a right in rem. It is called contract merely to bring it within the contract clause of the Constitution." ${ }^{36}$

I9r3, Viscount Haldane, Lord Chancellor, in Attenborough v.

\section{Solomon:}

"But the question which goes to the root of this case is one which renders such a proposition wholly beside the point. If I am right, there is no question here of an executor acting in the execution of his powers, so far as this residue is concerned. The executors had long ago lost their vested right of property as executors and become, so far as the title to it was concerned, trustees under the will. Executors they remained, but they were executors who had become divested, by their assent to the dispositions of the will, of the property which was theirs virtute officii; and their right in rem, their titile of property, had been transformed into a right in personam,-a right to get the

(I903) 194 U. S. 601, 606.

- (I904) I95 U. S. $375,382$.

* (I905) I97 U. S. 544, 575. 
property back by proper proceedings against those in whom the property should be vested if it turned out that they required it for payment of debts for which they had made no provision." 47

I914, Viscount Haldane, Lord Chancellor, in Sinclair v. Brougham:

"The difficulty of establishing a title in rem in this case arises from the apparent difficulty of following money. In most cases money cannot be followed. When sovereigns or bank notes are paid over as currency, so far as the payer is concerned, they cease ipso facto to be the subjects of specific title as chattels. If a sovereign or bank note be offered in payment it is, under ordinary circumstances, no part of the duty of the person receiving it to inquire into title. The reason of this is that chattels of such a kind form part of what the law recognizes as currency, and treats as passing from hand to hand in point, not merely of possession, but of property. It would cause great inconvenience to commerce if in this class of chattel an exception were not made to the general requirement of the law as to title. . . .

"That seems to be, so far as the doctrine of the common law is concerned, the limit to which the exception to the rule about currency was carried; whether the case be that of a thief or of a fraudulent broker, or of money paid under mistake of fact, you can, even at law, follow, but only so long as the relation of debtor and creditor has not superseded the right in rem."

I914, Lord Sumner, in Sinclair v. Brougham:

"Analogous cases have been decided with regard to chattels. They differ, no doubt, because of the fact that the property in the chattels remained unchanged, though identification and even identity of the subject-matter of the property failed, whereas here, except as to currency, and even there only in a restricted sense, the term property, as we use that term of chattels, does not apply, and, at least as far as intention could do it, both depositors and shareholders had given up the right to call the money or its proceeds their ozm, and had taken instead personal claims on the society." 49

${ }^{47}$ [1913] A. C. 76, 85.

${ }^{43}$ [1914] A. C. $398,418,419$.

1. [1914] A. C. $398,458$. 
I9I6, Mr. Justice Brandeis, in Kryger v. Wilson:

"If the plaintiff in error had not submitted himself to the jurisdiction of the court, the decree could have determined only the title to the land, and would have left him free to assert any personal rights he may have had under the contract."

(b) A multital right, or claim, (right in rem) is not always one relating to a thing, i. e., a tangible object: If the preceding discussion has served its various purposes, it must now be reasonably clear that the attempt to conceive of a right in rem as a right against $a$ thing should be abandoned as intrinsically unsound, as thoroughly discredited according to good usage, and, finally, as all too likely to confuse and mislead. It is desirable, next, to emphasize, in more specific and direct form, another important point which has already been incidentally noticed: that a right in rem is not necessarily one relating to, or concerning, a thing, i. e., a tangible object. Such an assumption, although made by Leake and by many others who have given little or no attention to fundamental legal conceptions, is clearly erroneous. The term right in rem (multital right) is so generic in its denotation as to include: I. Multital rights, or claims, relating to a definite tangible object: e. g., a landowner's right that any ordinary person shall not enter on his land, or a chattel owner's right that any ordinary person shall not physically harm the object involved,-be it horse, watch, book, etc. 2. Multital rights (or claims) relating neither to definite tangible object nor to (tangible) person, e. g., a patentee's right, or claim, that any ordinary person shall not manufacture articles covered by the patent; 3. Multital rights, or claims, relating to the holder's own person, e. g., his right that any ordinary person shall not strike him, or that any ordinary person shall not restrain his physical liberty, i. e., "falsely imprison" him; 4. Multital rights residing in a given person and relating to another person, e. g., the right of a father that his daughter shall not be seduced, or the right of a husband that harm shall not be inflicted on his wife so as to deprive him of her company and assistance; 5 . Multital rights, or claims, not relating directly to either a (tangible) person or a tangible object, e. g., a person's right that another shall not publish a libel of him, or a person's right

(1916) 37 Sup. Ct. Rep. 34, 35. 
that another shall not publish his picture,-the so-called "right of privacy" existing in some states, but not in all.

It is thus seen that some rights in rem, or multital rights, relate fairly directly to physical objects; some fairly directly to persons; and some fairly directly neither to tangible objects nor to persons.

It is, however, important to observe that there is a more specific Latin term, jus in re, which has been frequently used by able judges to indicate jural relations in rem (i. e., multital rights, privileges, powers, and immunities) directly concerning a tangible object, such as a piece of land, a vessel, etc. This form of expression appears to have been used by the classical Roman jurists almost exclusively in the more specific combination, jus in re aliena (easements, profits, etc.), as contrasted with jus in re propria; but the more generic jus in re was freely employed by the modern civilians,- -especially in opposition to a particular kind of $j u s$ in personam called jus ad rem..$^{52}$ The following explanations and examples of modern usage by able judges are worthy of careful and critical consideration:

I87x, Mr. Justice Markby, Elements of Law:

"It is necessary to distinguish carefully between a right in rem and a (so-called) real right. A real right is a right over a specific thing (a jus in re, as will be explained hereafter). Thus a right of ownership is a real right; it is also a right in rem. But a right to personal safety is not a real right, though it is a right in rem."

I9I4, Lord Dunedin, in Sinclair v. Brougham:

"The case of a chattel is easy: A shopkeeper delivers an article at the house of $B$. in mistake for the house of $A$. An action would lie against $B$. for restitution. Such an action could easily be founded on the right of property. To use the Roman phraseology, there would be a jus in re. And where there was a jus in $r e$ there would not be, I take

\footnotetext{
12 That is, if $A$ has a right in personam against B that the latter shall "transfer" some "legal interest," e. g., title of Blackacre, to A, A is said to have only a jus ad rem; whereas after conveyance made by $B$, A would have $j u s$ in re.

For very interesting instances of the use of the terms jus in re and jus ad rem in connection with attempts to explain the nature of uses and trusts, see Bacon, Uses (Circa 1602) Rowe's ed., pp. 5-6; Co. Lit. (I628) p. $272 \mathrm{~b}$.

Both of these passages are quoted in (rgr3) 23 YALE LAw JouRnAL, I6, notes $I$ and 2.

- Elements of Law (6th ed., rgo5) 99, note.
} 
it, any difficulty in finding a form of common law action to fit the situation. But the moment you come to deal with what in Roman phraseology is called a fungible, and especially when you deal with money, then the jus in re may disappear, and with it the appropriateness of such common law action. The familiar case is the paying of money by $A$. to $B$. under the mistaken impression in fact that a debt was due, when in truth there was no debt due. It was to fit cases of this sort that the common law evolved the action for money had and received."'ss

I9I4, Lord Kinnear, in Bank of Scotland v. Macleod:

"But to extend Lord Westbury's phrase so as to make it cover personal obligations which do not affect the real right of the obligor seems to me altogether extravagant. It was maintained in argument that every obligation with reference to any property or fund which involves a liability to account fell within the principle. If that were so every imperfect security, however invalid as a real right, would be effectual as a trust."

I855, Mr. Justice B. R. Curtis, in The Young Mechanic:

"But I will first inquire what right or interest is conferred by the statute, provided it intended to create such a lien, as exists by the general admiralty law upon foreign vessels.

"Though the nature of admiralty liens has douitless been long understood, it does not seem to have been described with fulness and precision, in England or this country. That it differs from what is called by the same name in the common law, is clear; for it exists independent of possession. The Bold Buccleugh, 22 Eng. L. \& Eq. 62; The Nestor, I Sumn. 73. That it is not identical with equitable liens, is equally clear; for the latter arise out of constructive trusts, and are neither $a$ jus ad rem, or a jus in re; but simply a duty, binding on the conscience of the owner of the thing, and which a Court of Equity will compel him specifically to perform. 2 Story's Eq. Jurisp. § I2I7; Ex parte Foster, 2 Story, R. I45; Clarke v. Southwick, I Curtis, 299. . . .

"In my opinion the definition given by Pothier of an hypothecation is an accurate description of a maritime lien under our law. "The right which a creditor-has in a thing of another, which right consists in the power to cause that

[I9I4] A. C. 398,43 I.

[Igr4] A. C. 3Ir, 324 
thing to be sold, in order to have the debt paid out of the price. This is a right in the thing, a jus in re.' Traité de l'Hypotheque, art. prelim. See also, Sanders's Justinian, page 227. . . .

"Whether he can make the seizure himself, only to be followed by a judicial sale, or must resort to a court for both, may be important as to remedy, but does not affect his ultimate and essential right. . . .

"Though tacitly created by the law, and to be executed only by the aid of a court of justice, and resulting in a judicial sale, it is as really a property in the thing as the right of a pledgee or the lien of a bailee for work. The distinction between a jus in $r e$ and a jus ad rem was familiar to lawyers of the middle ages, and is said then to have first come into practical use, as the basis of the division of rights into real and personal. Sanders' Intro. to Just. p. 49. A jus in re is a right, or property in a thing, valid as against all mankind. A $j u s$ ad rem is a valid claim on one or more persons to do something, by force of which a jus in $r e$ will be acquired. Pothier, Traité du Droit de Domaine, ch. Pretences; Hugo, His. du Droit Rom. vol. I, p. II8. . . .

"My opinion is, that the lien conferred by the local law was an existing incumbrance on the vessel, not divested or extinguished by the death or insolvency of the owner; and that, consequently, the decree of the District Court must be affirmed."

I900, Mr. Chief Justice Fuller, in The Carlos F. Roses:

"The right of capture acts on the proprietary interest of the thing captured at the time of the capture and is not affected by the secret liens or private engagements of the parties. Hence the prize courts have rejected in its favor the lien of bottomry bonds, of mortgages, for supplies, and of bills of lading. The assignment of bills of lading transfers the jus ad rem, but not necessarily the jus in rem. The jus in $r e$ or in rem implies the absolute dominion,the ownership independently of any particular relation with another person. The jus ad rem has for its foundation an obligation incurred by another. Sand. Inst. Just. Introd., xlviii ; 2 Marcade, Expl. du Code Napoleon, 350; 2 Bouvier, (Rawle's Revision), 73; The Young Mechanic, 2 Curtis, 404.

"Claimants did not obtain the jus in rem, and, according to the great weight of authority, the right of capture was
superior."

* (1855) 2 Curtis, 404, 406, 410, 4II, 412, 414

* (1900) I77 U. S. 655, 666. 
187o, Mr. Justice Foster, in Jacobs v. Knapp:

"That statute provides that 'any person who labors at cutting, hauling, or drawing wood, bark, logs, or lumber, shall have a lien thereon for his personal services, which lien shall take precedence of all other claims except liens on account of public taxes, to continue sixty days after the, services are performed, and may be secured by attachment.'

"At the common law the lien of a mechanic, manufacturer, or other laborer is neither a jus ad rem nor a jus in re: that is to say, it is not a right of property in the thing itself, or a right of action to the thing itself;' but it is a security, derived from a 'general principle of the common law, which gives to a man who has the lawful possession of a thing and has expended his money or his labor upon it, at the request of the owner, a right to retain it until his demand is satisfied.' . . .

"A lien, as we have seen, is a personal right, as well as an interest which can only be created by the owner, or. by his authority. If Fifield, by virtue of his contract with the defendants, had a lien upon the wood, the plaintiff could acquire no lien upon the property through him. The plaintiff, as a creditor of Fifield, could not attach and hold, as against the owner, at the common law, the property in which Fifield had but the qualified interest of a pledgee. Lovett v. Brozen, 40 N. H. 5II. Neither is a lien for the price of labor performed on an article assignable. Bradley v. Spofford, 23 N. H. 447. • .

"The statutes of liens have enlarged the privileges of the party who, at common law, could only as bailee avail himself of the lien, by substituting, in the enumerated cases, attachment of the property for retention of possession; but it would be quite anomalous to regard this process of attachment as applying in favor of a stranger against a party with whom the plaintiff never contracted, and who could in no proper sense be regarded as an attaching creditor. . . .957

The passage from Mr. Justice Foster-the last of the above quotations-seems open to comment. If at common law the lien of the mechanic, manufacturer or other laborer consists of the "right to retain" the "thing" in his possession or, to use Mr. Justice Foster's own later and more discriminating term, a "privilege" of retaining possession, this is certainly a "privilege" relating to a "thing." More than that, such privileges are multital privileges, or privileges in rem, existing not only

" (1870) 50 N. H. 71, 75. 
against the owner of the chattel but also against all persons in general, and correlating with no-rights in the latter. These multital privileges relate directly to the physical "thing"; and they are "rights" in the very broad sense of that term. It is difficult, therefore, to see why the term jus in re should not be applicable. For the latter term does not seem to be confined to rights in the sense of claims, this being shown by the abovequoted opinion of Mr. Justice Curtis, whose characterization of common-law liens differs from that of Mr. Justice Foster. It is also clear that the lienor has, by virtue of his possession per se, rights in rem against all others that they shall not disturb that possession or harm the object possessed. These last are rights or claims literally relating to the thing; and, therefore, so far at least as the literal meaning of $j u s$ in $r e$ is concerned there seems to be no reason why the latter expression should not be applied. It is true that if the lienor were to surrender possession he would thereby divest himself of his privilege (against the owner) and his rights, or claims, against the owner and others; but while those relations exist they concern the thing, and that fact is obviously not negatived by the possibility of their being divested.

The passage last quoted from Mr. Justice Markby and also the extracts from the opinions of Lord Kinnear and Mr. Justice Curtis show that those rights in rem which directly relate to things-land, vessels, etc.-instead of being called jus in re are, occasionally denominated "real"-_a term meaning literally, of course, "relating to a thing." "Real rights" in this sense are opposed to rights in personam relating to things. Thus, e. g., if $\mathrm{A}$ is owner of a horse, he has jus in re or "real rights"; if, on the other hand, $X$ is under contract to transfer the ownership of a horse to $A$, the latter has that sort of right in personam which would sometimes be called jus ad rem, or "personal right." In the restricted sense now referred to, it seems clear that real rights as a class also exclude both rights in personam and rights in rem that do not relate directly to things, or tangible objects. The following passages may be considered with advantage:

I914, Professor E. C. Clark, History of Roman Law: Jurisprudence:

"Jura realia and personalia are expressions occasionally used by modern civilians as adjectival forms for jura in rem and in personam, but only as confined to Property Law. (E. G., the translator of Mackeldey, Pr. ii. \$ I5. 
Austin ( $T$. and $N$. ii. 5, pp. 977,$978 ;$ St. Note on Lect. I4, p. I84) identifies the pairs without the above qualification.) This at least seems to be the meaning given by Savigny to jura realia, if represented by the corresponding German dingliche Rechte. (System, I, § 56, p. 369 . Alle mögliche Rechte an Sachen . . fassen wir unter dem gemeinsamen Namen der dinglichen Rechte zusammen.)

I855, Mr. Justice B. R. Curtis, in The Young Mechanic:

"The distinction between a jus in re and a jus ad rem was familiar to lawyers of the middle ages, and is said then to have first come into practical use, as the basis of the division of rights into real and personal. Sanders' Intro. to Just. P. 49. A jus in re is a right, or property in a thing, valid as against all mankind. A jus ad rem is a valid claim on one or more persons to do something, by force of which a jus in re will be acquired. Pothier, Traité du Droit de Domaine, ch. Pretences; Hugo, His. du Droit Rom. vol. I, p. I18."

I914, Lord Kinnear, in Bank of Scotland v. Macleod:

"But to extend Lord Westbury's phrase so as to make it cover personal obligations which do not affect the real right of the obligor seems to me altogether extravagant. It was maintained in argument that every obligation with reference to any property or fund which involves a liability to account fell within the principle. If that were so every imperfect security, however invalid as a real right, would be effectual as a trust."

Even when restricted as above indicated, the pair of terms, "real" and "personal," seems an undesirable one for Englishspeaking lawyers and judges because those words are already definitely appropriated to different and independent classifications and are constantly applied in connection with the latter. Thus, e. g., we have "real property" and "personal property"; and this classification is obviously not parallel with that of "real rights" and "personal rights"-both of the latter terms being applicable either to "personal property" relations or to "real property" relations. Then too, the expression "personal rights" is espe-

${ }^{s}$ History of Roman Law: Jurisprudence (I914) Vol. II, p. 7I8.

(1855) 2 Curtis, 404, 4I2.

${ }^{\infty}$ [rgr4] A. C. 3 Ir, 324. 
cially misleading in its connotation because, literally, it tends to suggest rights concerning a person as the object to which the rights relate, that is, either the person who holds the rights or some other person. It is therefore most fortunate that the pair of terms, "real rights" and "personal rights," is not at all common in judicial opinions or in legal treatises. Over against this, however, it must be recognized that courts not infrequently use a somewhat similar pair of terms, viz., the expression "personal rights" or "personal claims" in opposition to some such expression as "property rights," "title to land," "interest in the thing," etc. ${ }^{81}$

Finally, as regards this particular matter, it must be regretted that some authors, though no courts whatever so far as has been observed, use the terms "real rights" and "personal rights" as exact equivalents, respectively, for all kinds of rights in rem (whether relating directly to things or persons or to neither) and all kinds of rights in personam. It is greatly to be hoped that such an unusual and, for the English law, misleading use of terms will not become at all common.

(c) A single multital right, or claim, (right in rem) correlates with a duty resting on one person alone, not with many duties (or one duty) resting upon all the members of a very large and indefinite class of persons: Though fairly implicated with what has been said in the "preliminary" explanation of ideas and terms, ${ }^{02}$ this proposition now requires more detailed consideration; for it represents a considerable departure from the explanations or analyses to be found in treatises on jurisprudence or in books on particular branches of the law. Let us first have definitely before us some typical passages:

I832, Professor John Austin, Lectures on Jurisprudence, or the Philosophy of Positive Law:

"All rights reside in persons, and are rights to acts or forbearances on the part of other persons. . . .

"The essentials of $a$ right in rem are these:

"It resides in $a$ determinate person, or in determinate persons, and avails against other persons universally or

"See the quotations given ante: Mr. Justice Holmes, pp. 730-73r; Mr. Justice Brandeis, p. 733; Lord Sumner, p. 732.

See also the term "personal rights" as used by Mr. Justice Holmes, dissenting, in the very recent case of Southern Pacific Co. v. Jensen (U. S. Sup. Ct., May 2r, rgr7).

- See ante, pp. 718 ff. 
generally. Further, the duty with which it correlates, or to which it corresponds, is negative: that is to say, $a$ duty to forbear or abstain. .. .

"The duty which correlates with [a right in rem] attaches upon persons generally.","ss

I87r, Mr. Justice Markby, Elements of Law:

"The persons to whom a right in rem belongs may be changed to any extent within the limits allowed by the law, but the persons upon whom the duty corresponding to a right in rem is imposed cannot be changed, because all persons are under that duty."

I880, Professor Thomas Erskine Holland, Elements of Jurisprudence:

" $A$ right is available either against a definite person or persons, or against all persons indefinitely....

"This distinction between rights has been expressed by calling a right of the definite kind a right in personam, of the indefinite kind a right in rem."

I902, Mr. Solicitor-General Salmond, Jurisprudence:

" $A$ real right corresponds to $a$ duty imposed on persons in general. . . The indeterminate incidence of the duty which corresponds to $a$ real right, renders impossible many modes of dealing with it which are of importance in the case of personal rights." ${ }^{.66}$

I9I5, Professor Harlan Fiske Stone, Law and its Administration:

"One may have $a$ right against all members of the community indifferently. Thus one has the right not to have his person or his property unlawfully interfered with, and this right exists generally againdt all members of the community." $"$ "7

I9I6, Professor Samuel Williston, Is the Right of an Assignee of a Chose in Action Legal or Equitable?

as Jurisp. (5th ed., 1885) Vol. I, pp. 368, 394, 371, 586.

" Elements of Law (6th ed., 1905) pp. 91, 99.

- Jurisp. (10th ed., 1906) p. r39.

ourisp. (4th ed., Igr3) pp. 202, 203.

"Law and its Administration (1915) p. 53. 
"Though legal ownership is conceived fundamentally as $a$ right good against all the world, actual instances of such ownership are often much more narrowly limited. The owner of a chattel which has been stolen from him is likely to find his right against the world considerably qualified if the thief is in a place where the principles of market overt prevail."'88

In opposition to the ideas embodied in the passages just given, ${ }^{69}$ it is submitted that instead of there being a single right with a single correlative duty resting on all the persons against whom the right avails, there are many separate and distinct rights, actual and potential, each one of which has a correlative duty resting upon some one person. Repeating a hypothetical case put above, let us suppose that $A$ is the owner of Blackacre and $\mathrm{X}$ is the owner of Whiteacro. It may be assumed further that, in consideration of $\$ 100$ actually paid by $A$ to $B$, the latter agrees with $A$ never to enter on $X$ 's land, Whiteacre; also that $C$ and $D$, at the same time and for separate considerations, make respective similar agreements with $A$. In such a case $A$ 's respective rights against $\mathrm{B}, \mathrm{C}$, and $\mathrm{D}$ are clearly rights in personam, or paucital rights. Surely no one would assert that $A$ has only a single right against $B, C$, and $D$, with only a single or unified duty resting on the latter. A's right against $B$ is entirely separate from the other two. B may commit a breach of his duty, without involving any breach of C's duty by $C$ or any breach of D's duty by $D$. For, obviously, the content of each respective duty differs from each of the others. To make it otherwise $C$ and $D$ would have to be under a duty or duties (along with $B$ ) that $B$ should not enter on X's land. Even if that were the case, there would be said to be three separate duties unless $B, C$, and $D$ bound themselves so as to create a so-called joint obligation. In the latter case alone would there be said to be a single right and a single (joint) duty. Going beyond this direct analysis of the situation, it seems clear that the three respective "right-duty" relations of $A$ and $B, A$ and $C$, and $A$ and $D$ respond to every test of separateness and independence. A might discharge $B$ from his duty to $A$, thus (in equivalent terms) creating a privilege of entering as against $A$ (not as against $X$, of course); yet,

- (I916) 30 HaRv. L. REv. 97, 98.

- See also the various judicial opinions from which quotations are given ante pp. 729-733. 
obviously, the respective duties of $C$ and $D$ would continue the same as before.

Point for point, the same considerations and tests seem applicable to $A$ 's respective rights in rem, or multital rights, against $B, C, D$, and others indefinitely that they, respectively considered, shall not enter on Blackacre. It is not a case of one joint duty of the same content resting on all-e. g., that $\mathrm{B}$ should not enter on Blackacre. ${ }^{70}$ Consistently with this view, A might, e. g., extinguish B's duty or, in other words, grant B the privilege of entering by giving "leave and license" to do so. In such event, of course, the respective duties of C, D, E, and all others would continue to exist, precisely as before.

In order to see even more clearly that the supposed single right in rem correlating with "a duty" on "all" persons really involves as many separate and distinct "right-duty" relations as there are persons subject to a duty, it may be worth while to reverse the situation somewhat, and consider, in anticipation of a more general treatment at a later point, the subject of duties in rem, or multital duties. Thus, e. $\mathrm{g} ., \mathrm{X}$ is under duty not to strike $\mathrm{R}$,

"Compare, however, special cases like Thorpe v. Brumfitt (1873) L. R. $8 \mathrm{Ch}$. App. 650, involving a suit for an injunction against several defendants for disturbance of plaintiff's right of way. Lord Justice James said: "The plaintiff cannot complain, unless he can prove an obstruction which injures him. The case is not like one of trespass, which gives a right of action though no damage be proved. In the present case, I cannot come to any other conclusion than that arrived at by the Master of the Rolls, that the right of access to the inn-yard has been interfered with in a way most prejudicial to the Plaintiff. Nothing can be much more injurious to the owner of an inn than that the way to his yard should be constantly obstructed by the loading and unloading of heavy waggons. If a person who was going to put up his horses at the inn was stopped by the loading or unloading of waggons, he would probably at once go to another inn. Then it was said that the Plaintiff alleges an obstruction caused by several persons acting independently of each other, and does not shew what share each had in causing it. It is probably impossible for a person in the Plaintiff's position to shew this. Nor do I think it necessary that he should shew it. The amount of obstruction caused by any one of them might not, if it stood alone, be sufficient to give any ground of complaint, though the amount caused by them all may be a serious injury. Suppose one person leaves a wheelbarrow standing on a way, that may cause no appreciable inconvenience, but if a hurdred do so, that may cause a serious inconvenience, which a person entitled to the use of the way has a right to prevent; and it is no defence to any one person among the hundred to say that what he does causes of itself no damage to the complainant." 
$\mathrm{S}, \mathrm{T}$, or any other ordinary member of the community. Are we to say that, as regards these many persons, $X$ has but a single duty, ${ }^{71}$ and that, correlatively, there is but a single right held by $R, S, T$, and all the others? Manifestly not, for each one of these persons has a distinct and independent right; and any one of such independent rights might cease to exist without in the least affecting the others. If, e. g., $R$ threatens bodily harm to $X, R$ 's right that $X$ shall not strike him becomes thereby extinguished, and a no-right in $R$ substituted; or, correlatively, in such contingency, $X$ 's duty to $R$ ceases, and $X$ acquires a privilege of self-defense against $R$. But such change in no way affects the entirely distinct relations existing between $\mathrm{X}$ and the various other persons involved. As regards the separateness and relativity of all "right-duty" relations, the following judicial reasoning seems accurate and persuasive:

I908, Mr. Justice Connor, in $M c G h e e$ v. R. Co.:

"It is elementary that plaintiff had no cause of action against defendants for placing the dynamite in the shanty. He must establish some relation between defendants and himself from which a duty to him is imposed upon defendants. "The expression "duty" properly imports a determinate person to zehom the obligation is owing, as well as the one who owes the obligation. There must be two determinate parties before the relationship of obligor and obligee of a duty can exist." "?2

With this passage we may well compare the instructive opinion of an eminent English judge emphasizing the distinct and relative character of each "privilege-no-right" relation connected with a given matter, his observations being equally applicable to "right-duty" relations :

1906, Lord Collins, M. R., in Thomas v. Bradbury, Agnew, \& Co., Ltd.:

"Some would say yes: compare Sir Frederick Pollock, Jurisprudence (2d ed., 1904) 64: "Doubtless there are duties without any determinate rights corresponding to them : indeed, this is the case, in any view, with the negative duties which we owe to the community at large. For my duty not to damage other people's goods, for example, is one duty, not millions of separate duties owed to every one who has anything to be damaged, or in respect of every separate chattel of any value."

II (1908) I47 N. C. $142,146$. 
"The right" [privilege] "of fair comment, though shared by the public, is the right" [privilege] "of every individual who asserts it, and is, qua him, an individual right whatever name it be called by, and comment by him which is coloured by malice cannot from his standpoint be deemed fair. He, and he only, is the person in whose motives the plaintiff in the libel action is concerned, and if he, the person sued, is proved to have allowed his view to be distored by malice, it is quite immaterial that somebody else might without malice have written an equally damnatory criticism. The defendant, and not that other person, is the party sued."7s

If, then, the foregoing line of reasoning be sound, the following points would seem to be reasonably clear: A right in rem, or multital right, correctly understood, is simply one of a large number of fundamentally similar rights residing in one person; and any one of such rights has as its correlative one, and only one, of a large number of general, or common, duties,-that is, fundamentaly similar duties residing respectively in many different persons. Similarly, a duty in rem, or multital duty, is one of a large number of fundamentally similar duties residing in one person; and any one of such duties has as its correlative one of a large number of general, or common, rights, or claims, - that is, fundamentally similar rights, or claims, residing respectively in many different persons. It is therefore to be hoped that, instead of continuing to be used to indicate the entire multiplicity of separate and independent rights, or claims, that a person may have against many others, the term right in rem may gradually come to be used to represent one, and only one, of this multiplicity of distinct rights. Whatever be the fate of the concept and term, right in rem, in this regard, it is surely of the utmost importance that the various possible analyses and meanings involved be carefully pondered and understood; and, in the meanwhile, the term "multital"-free as it is from any previous hazy connotations-will without question serve definitely to indicate one, and one only, of such a multiplicity of rights as is now under consideration.

(d) A multital right, or claim, (right in rem) should not be confused with any co-existing privileges or other jural relations that the holder of the multital right or rights may have in respect to the same subject-matter: As already incidentally noticed, it is

${ }^{73}[1906] 2$ K. B. $627,638$. 
feared that the exact nature of multital rights has been greatly obscured not only by the habitual tendency to treat a multiplicity of fundamentally similar rights, or claims, as if they were only one, but also by the equally strong tendency to include under the hazy blanket term, right in rem, especially in the case of tangible objects, the multiplicity of privileges and other jural relations that the holder of the multital right or rights may have.

Suppose, for example, that $A$ is fee-simple owner of Blackacre. His "legal interest" or "property" relating to the tangible object that we call land consists of a complex aggregate of rights (or claims), privileges, powers, and immunities. ${ }^{74}$ First: $\mathrm{A}$ has multital legal rights, or claims, that others, respectively, shall not enter on the land, that they shall not cause physical harm to the land, etc., such others being under respective correlative legal duties. Second: A has an indefinite number of legal privileges of entering on the land, using the land, harming the land, etc., that is, within limits fixed by law on grounds of social and economic policy, he has privileges of doing on or to the land what he pleases; and correlative to all such legal privileges are the respective legal no-rights of other persons. Third: A has the legal power to alienate his legal interest to another, i. e., to extinguish his complex aggregate of jural relations and create a new and similar aggregate in the other person; also the legal power to create a life estate in another and concurrently to create a reversion in himself; also the legal power to create a privilege of entrance in any other person by giving "leave and license"; and so on indefinitely. Correlative to all such legal powers are the legal liabilities, in other persons,- this meaning that the latter are subject, nolens volens, to the changes of jural relations involved in the exercise of A's powers. Fourth: A has an indefinite number of legal immunities, using the term immunity in the very specific sense of non-liability or non-subjection to a power on the part of another person. Thus he has the immunity that no ordinary person can alienate A's legal interest or aggregate of jural relations to another person; the immunity

\footnotetext{
${ }^{74}$ See (1913) 23 Yale Law Journal, 21, 24, 59. Compare also Mr. Justice Foster, in Pullitzer v. Livingston (1896) 89 Me. 359: "With all the rights, privileges, and powers incident to ownership," etc.

See also Professor Arthur L. Corbin, Offer and Acceptance and Some of the Resulting Legal Relations (I9I7) 26 YALE LAW JourNaL, I72.
} 
that no ordinary person can extinguish A's own privileges of using the land; the immunity that no ordinary person can extinguish A's right that another person $X$ shall not enter on the land or, in other words, create in $\mathrm{X}$ a privilege of entering on the land. Correlative to all these immunities are the respective legal disabilities of other persons in general.

In short, $\mathrm{A}$ has vested in himself, as regards Blackacre, multital, or in rem, "right-duty" relations, multital, or in rem, "privilege-no-right" relations, multital, or in rem, "powerliability" relations, and multital, or in rem, "immunity-disability" relations. It is important, in order to have an adequate analytical view of property, to see all these various elements in the aggregate. It is equally important, for many reasons, that the different classes of jural relations should not be loosely confused with one another. A's privileges, e. g., are strikingly independent of his rights or claims against any given person, and either might exist without the other. Thus A might, for $\$ 100$ paid to him by $B$, agree in writing to keep off Blackacre. $A$ would still have his rights or claims against $B$, that the latter should keep off, etc.; yet, as against $B$, A's own privileges of entering on Blackacre would be gone. On the other hand, with regard to $X$ 's land, Whiteacre, $A$ has, as against $B$, the privilege of entering thereon; but, not having possession, he has no right, or claim, that B shall not enter on Whiteacre.

Not only as a matter of accurate analysis and exposition, but also as a matter of great practical consequence and economic significance, the property owner's rights, or claims, should be sharply differentiated from his privileges. It is sometimes thought that A's rights, or claims, are created by the law for the sole purpose of guarding or protecting A's own physical user or enjoyment of the land, as if such physical user or enjoyment of the land were the only economic factor of importance. A moment's reflection, however, shows that this is a very inadequate view. Even though the land be entirely vacant and $A$ have no intention whatever of personally using the land, his rights or claims that others shall not use it even temporarily in such ways as would not alter its physical character are, generally, of great economic significance as tending to make others compensate $A$ in exchange for the extinguishment of his rights, or claims, or in other words, the creation of privileges of user and enjoyment. This has been emphasized by an eminent English judge: 
1874, Lord Selborne, Chancellor, in Goodson v. Richardson: ${ }^{75}$

"It is said that the objection of the plaintiff to the laying of these pipes in his land is an unneighborly thing, and that his right is one of little or no value, and one which Parliament if it were to deal with the question, might possibly disregard. What Parliament might do, if it were to deal with the question, is, I apprehend, not a matter for our consideration now, as Parliament has not dealt with the question. Parliament is, no doubt, at liberty to take a higher view upon a balance struck between private rights and public interests than this Court can take. But with respect to the suggested absence of value of the land in its present situation, it is enough to say that the very fact that no interference of this kind can lawfully take place without his consent, and without a bargain with him, gives his interest in this land, even in a pecuniary point of view, precisely the value which that power of veto upon its use creates, when such use is to any other person desirable and an object sought to be obtained." "76

Even so able and cautious a thinker as Austin seems to have confused legal privileges with legal rights (in the sense of claims), and also, at times, to have confused mere physical power and liberty both with legal privileges and with legal rights. Probably because of the very failure to make these necessary and important discriminations, he appears to have overlooked, or at least seriously underrated, the practical and economic significance of the landowner's "right-duty" relations considered wholly apart from their being guardians of the "privilegeno-right" relations, or protectors of the physical liberty and power involved in the exercise of such legal privileges:

I832, Professor John Austin, Lectures on Jurisprudence, or the Philosophy of Positive Law:

"Now the ends or purposes of different rights are extremely various. The end of the rights in rem which are conferred over things, is this: that the entitled party may deal with, or dispose of, the thing in question in such or such a manner and to such or such an extent. In order to that end, other persons generally are laid under duties to forbear or abstain from acts which would defeat or thwart it. . . .

${ }^{25}$ (1874) L. R. 9 Ch. App. 221, 223.

Compare Henry Pitney, V. C., in Hernessy v. Carmony (1892) 50 N. J. Eq. 616. 
"As I stated in my last lecture, I mean by property or dominion (taken with the sense wherein I use the term, for the present) any such right in rem (of limited or unlimited duration) as gives to the party in whom it resides an indefinite power or liberty of using or dealing with the subject: A power or liberty of using or dealing with the subject which is not capable of exact circumscription or definition; which is merely limited, generally and indefinitely, by the sum of the duties (relative and absolute) incumbent on the owner or proprietor. . . .

"The power of user and the power of exclusion are equally rights to forbearances on the part of other persons generally. By virtue of the right or power of indefinitely using the subject, other persons generally are bound to forbear from disturbing the owner in acts of user. By virtue of the right or power of excluding other persons generally, other persons generally are bound to forbear from using or meddling with the subject. The rights of user and exclusion are so blended, that an offence against the one is commonly an offence against the other. I can hardly prevent you from ploughing your field, or from raising a building upon it, without committing, at the same time, a trespass. And an attempt on my part to use the subject (as an attempt, for example, to fish in your pond) is an interference with your right of user as well as with your right of exclusion. But an offence against one of these rights is not of necessity an offence against the other. If, for example, I walk across your field, in order to shorten my way to a given point, I may not in the least injure you in respect of your right of user, although I violate your right of exclusion. Violations of the right of exclusion (when perfectly harmless in themselves) are treated as injuries or offences by reason of their probable effect on the rights of user and exclusion. A harmless violation of the right of exclusion, if it passed with perfect impunity, might lead, by force of the example, to such numerous violations of the right as would render both rights nearly mugatory." 77

In these various passages, and especially in the last one, Austin uses the term "right" indiscriminately and confusedly to indicate both those jural relations that are legal rights, or claims, and those that are legal privileges-a lapse all the more surprising in view of the fact that the learned and painstaking author had previously been carefill to emphasize the proposition that "the term 'right' and the term 'relative duty' signify the same

"Jurisp. (5th ed., 1885) Vol. I, p. 397, Vol. II, pp. 799, 802, 808. 
notion considered from different aspects."78 Such a delimitation of "right" clearly excludes "legal privilege"; for the correlative of the latter, or "the same notion" from a "different aspect," is, of course, "no-right" or "no-olaim."

More or less similar blending of legal concepts and terms in connection with the subject of rights in rem seems to find place not only in well-known works on jurisprudence but also in various treatises or monographs on particular branches of the law. ${ }^{79}$ Indeed it is not unlikely that the later writers have in this respect but followed the lead of Austin, as they have in so many other matters of legal analysis. The following passages will serve to show how general is the usage referred to, and, it is believed, will also indicate how such a usage tends to hinder and obscure correct analysis and clear understanding of legal problems:

I87r, Mr. Justice Markby, Elements of Lazv:

"Thus in the case of a contract between A and B, the right of $A$ to demand performance of the contract exists against $B$ only; whereas in the case of ownership, the right to hold and enjoy the property exists against persons generally. This distinction between rights is marked by the use of terms derived from the Latin: the former are called rights in personam; the latter are called rights in rem." 80

1880, Prnfessor Thomas Erskine Holland, Elements of Jurisprudence:

"A right is available either against a definite person or persons, or against all persons indefinitely. A servant, for instance, has a right to his wages for the work he has

7s Jurisp. (5th ed., I885) Vol. I, p. 395.

T2 It is, of course, possible for a given writer to "impose" on a term what meaning he will, within the principle of the following:

"When $I$ use a'word,'-Humpty Dumpty said, in rather a scornful tone,- it means just what I choose it to mean, neither more nor less.'

" 'The question is,' said Alice,-'whether you can make words mean so many different things?'

"The question is,' said Humpty Dumpty,- 'which is to be the master? That's all." Through the Looking Glass, Chap. VI.

If, however, this more or less arbitrary plan be pursued, it is at least desirable that it be done premeditatedly, and that adequate notice be given. It is, moreover, believed that, in the cases put in the text, the difficulties involved are concerned primarily with concepts rather than terms.

${ }^{\circ}$ Elements of Law (6th ed., I905) p. 98. 
done, available against a definite individual, his master; while the owner of a garden has a right to its exclusive enjoyment available against no one individual more than another, but against everybody."

rgo2, Mr. Solicitor-General Salmond, Jurisprudence:

"My right to the peaceable occupation of my farm is a real right, for all the world is under a duty towards me not to interfere with it. . . I have a real right to the use and occupation of my own house; I have a personal right to receive accommodation at an inn. . . ."

1874, Mr. Stephen Martin Leake, Law of Property in Land:

"Rights to things, jura in rem, have for their subject some material thing, as land or goods, which the owner may use or dispose of in any manner he pleases within the limits prescribed by the terms of his right. A right of this kind imports in all persons generally the correlative negative duty of abstaining from any interference with the exercise of it by the owner; and by enforcing this duty the law protects and establishes the right. But a right of this kind does not import any positive duty in any determinate person, or require any act or intervention of such person for its exercise and enjoyment." ${ }^{\text {s3 }}$

I887, Professor James Barr Ames, Purchase for Value without Notice:

"The most striking difference between property in a thing and property in an obligation is in the mode of enjoyment. The owner of a house or a horse enjoys the fruits of ownership without the aid of any other person. The only way in which the owner of an obligation can realize his ownership is by compelling its performance by the obligor. Hence, in the one case, the owner is said to have a right in rem, and, in the other, a right in personam." 84

I9I5, Professor Harlan Fiske Stone, Law and its Administration:

"It will be noted that the essential difference between a right in rem and a right in personam is that a right in rem may be enjoyed by the possessor of it without the inter-

"Elements of Jurisprudence (Ioth ed., I906) p. 139.

Jurisp. (4th ed., I9r3) pp. 202, 203.

saw of Property in Land (Ist ed., 1874) p. 2.

s (1887) I HaRv. L. REV. I, 9. 
vention or aid of any other person, whereas the possessor of a right in personam can enjoy his possession or ownership of it only by compelling the obligor to perform the obligation which gives use to the right. . .

"Rights in rem include generally all of those rights commonly spoken of as property rights; that is to say, rights to possess, use, and enjoy things, which rights are good and enforceable against all the world." 85

I916, Professor Samuel Williston, Is the Right of an Assignee of a Chose in Action Legal or Equitable?

"Though legal ozenership is conceived fundamentally as a right good against all the world, actual instances of such ownership are often much more narrowly limited."so

(e) A multital primary right, or claim, (right in rem) should, regarding its character as such, be carefully differentiated from the paucital secondary right, or claim, (right in personam) arising from a violation of the former: Using again the hypothetical case involving $A$ as owner of Blackacre, it is clear that if $B$ commits a destructive trespass on A's land, there arises at that moment a new right, or claim, in favor of $A,-i$. e., a so-called secondary right that $B$ shall pay him a sum of money as damages; and of course $B$ comes simultaneously under a correlative duty. Similarly if $C$ commits a battery on A, or if $D$ alienates the affections of $A$ 's wife; and so on indefinitely. In each of these cases the secondary right-e. g., that against $\mathrm{B}$-is a paucital right, or claim, i. e., a right in personam. The entire "right-duty" relation would be one of the class of relations in personam designated in Roman law by the term obligatio. More specifically, the relation would be known as an obligatio ex delicto. This is brought out by the language of an eminent judge:

I904, Mr Justice Holmes, in Slater v. Mexican National $R . R$. Co.:

"We assume for the moment that it was sufficiently alleged and proved that the killing of Slater was a negligent crime within the definition of Article II of the Penal Code, and, therefore, if the above sections were the only law bearing on the matter, that they created a civil lia

${ }^{8}$ Law and its Administration (1915) pp. 5I, 54, 57.

- (I9I6) 3o Harv. L. Rev. $97,98$. 
bility to make reparation to any one whose rights were infringed. ...

"The theory of the foreign suit is that .. . the act complained of . . gave rise to an obligation, an obligatio ...."gi

This analysis seems applicable even in the case of a tort consisting of wrongfully dispossessing an owner of a tangible movable object. Thus, if $\mathrm{Y}$ wrongfully takes possession and control of X's horse, there arises a duty in $\mathrm{Y}$ to return the animal to $X$; and, of course, $X$ gets a correlative right. The latter is a paucital right, or right in personam; for there are no fundamentally similar rights against persons in general. This is true even though, of course, $X$ 's rights against others that they shall not convert or harm the horse while in Y's possession are rights in rem. The following passage is apposite:

I900, Mr. Chief Justice Holmes, in Tyler v. Court of Registration:

"But it is said that this is not a proceeding in rem. It is certain that no phrase has been more misused. In the past it has had little more significance than that the right alleged to have been violated was a right in rem. Austin thinks it necessary to quote Leibnitz for the sufficiently obvious remark that every right to restitution is a right in personam. ${ }^{388}$

That this distinction is not always carefully observed may be seen from a consideration of the quotations next to be presented.

(f) $A$ multital primary right, or claim, (right in rem) should not, regarding its character as such, be confused with, or thought dependent on, the character of the proceedings by which it (and the secondary right arising from its violation) may be vindicated: Owing to limitations of space this matter cannot be given here all the attention that it deserves; and the more complete discussion must be reserved for another place. Some of the more important points should, however, be noticed in the present context.

At least two tendencies are occasionally to be. observed by way of confusing the nature of primary rights (as in personam or in rem) with the character of the proceedings by which they may be vindicated. Both of these tendencies are believed to be

" (1904) I94 U. S. I20, I25.

* (1900) I75 Mass. 71, 76. 
founded on seriously erroneous notions that ought, if possible, to be dissipated. Each of them will, therefore, be briefly discussed.

First: It is sometimes supposed that to have a right in rem concerning a tangible object of which the owner has been wrongfully dispossessed means that he may recover possession of the object itself, by self-help or action, from the first wrongdoer or any subsequent party holding possession as vendee or bailee of the first wrongdoer, or as wrongful taker from the latter. Thus:

1890, Professor James Barr Ames, Disseisin of Chattels:

"Trespass, however, was a purely personal action; it sounded only in damages. The wrongful taking of chattels was, therefore, a more effectual disseisin than the ouster from land. The dispossessed owner of land, as we have seen, could always recover possession by an action. Though deprived of the res, he still had a right in rem. The disseisor acquired only a defeasible estate. One whose chattel had been taken from him, on the other hand, having no means of recovering it by action, not only lost the res, but had no right in rem. The disseisor gained by his tort both the possession and the right of possession; in a word, the absolute property in the chattel taken. ...

"Today, as everyone knows, neither a trespasser, nor one taking or buying from him, nor the vendee of a bailee, either with or without delivery by the latter, acquires the absolute property in the chattel taken or bailed. The disseisee of goods, as well as the disseisee of land, has a right in rem. The process by which the right in personam has been transformed into a real right may be traced in the expansion of the writs of replevin and detinue, and is sufficiently curious to warrant a slight digression. . . .

"The disseisee's right in rem, however, was still a quali fied right; for replevin was never allowed in England against a vendee or bailee of a trespasser, nor against a second trespasser. It was only by the later extension of the action of detinue that a disseisee finally acquired a perfect right in rem. Detinue, although its object was the recovery of a specific chattel, was originally an action ex contractu. It was allowed only against a bailee or against a vendor, who after the sale and before delivery was in much the same position as a bailee. ...

"So long as the adverse possession continues, the dispossessed owner of the chattel has, manifesily, no power of present enjoyment. Has he lost also the power of alienation? His right in rem, if analyzed, means a right to recover possession by recaption or action."

- (I8go) 3 HaRv. I. REv. 25, 28, 29, 30, 3I, 33, 34, 337. 
As indicated by the passages quoted, Professor Ames seems to have thought that for the owner, after dispossession, to have rights in rem would require the remedy of specific recovery of the tangible object. This, however, seems to involve a blending or confusing of substantive relations and adjective relations. If $\mathrm{A}$, the owner of a tangible movable object, is dispossessed by $\mathrm{B}$, $A$, under modern authorities, has rights against all persons that the object should not be harmed or "converted"; and these rights could be vindicated by an action on the case or by an action of trover, as the facts might demand. It is clear, moreover, that such rights would exist, as multital rights, or rights in rem, even though no possessory remedy were open to A.

If we may judge by the passages quoted above, it seems not unlikely that Professor Ames, because of assuming that a right in rem concerning physical objects involves necessarily, in case of dispossession, the remedy of recovery of possession, would apparently have asserted that in the early days even a chattel owner in actual possession did not have " $a$ right in rem"; $; 0$ and it is clear, in any event, that the possibility of regaining possession by action or self-help is frequently assumed to be of the essence of "a right in rem."

This, however, seems a very inadequate and inexact view. Even in the days when wrongful dispossession operated virtually to divest the legal interest of the chattel owner, it was still true that prior to any such dispossessing of the physical object and concomitant divesting of the legal interest he had rights in rem against persons in general that they should not harm the object or take the object from the owner; and these respective multital rights, or rights in rem, could, as Professor Ames himself points out, be vindicated by trespass or other action brought to secure damages. $^{802}$ In other words, the chattel owner's rights, so long as he had them, were rights in rem, even though in the early period now referred to (middle of the thirteenth century) he

${ }^{\infty}$ Compare Ames, Disseisin of Chattels (I890) 3 Harp. L. REv. 3I4, passim; consider especially the statement: "A true property may, therefore, be shortly defined as possession coupled with the urimited right of possession." This definition would seem to involve a serious confusion of physical relations with legal relations.

Compare also Ames, Lectures on Legal History (rgr3) p. 76, passage quoted post, pp. 758-759.

${ }^{\infty}$ See Ames, Lectures on Legal History (rgr3) pp. 6o, n. I, I78 ff.

For judicial consideration of the early history of the action of trespass, see Admiralty Commissioners v. S. S. Amerika [IgI7] A. C. 38. 
was subject to the liabilities of their being virtually divested by a wrongful taking, - there being, correlatively, a power in the wrongdoer thus to divest the interest of the chattel owner.

Fundamentally similar legal powers and correlative liabilities involving the divesting of "legal" an "equitable" rights in rem (and other jural relations belonging to the particular aggregates involved) have existed from the earliest times. Such powers are created by the law on various grounds of policy and convenience, - the teleology underlying each particular instance not being difficult to discover. In this place a bare enumeration of some of such powers must suffice: I. The power of sale in market overt to a bona fide purchaser; 2. The power of even a thief having possession of money but not, of course, the "ownership" thereof, to create a good title in a bona fide "purchaser," the whole country being in this case, so to say, "market overt" because of the necessity of free circulation of money, and it being too inconvenient for the transferror to produce or the transferee to examine an "abstract of title"; 3. The power or powers of a grantor and second grantee of realty, under the recording acts, to extinguish the interest of the first grantee by a conveyance to the second grantee as an innocent purchaser and the prior recording of the latter's deed; ${ }^{83}$ 4. The statutory power of a factor, in certain cases, to create a good title in an innocent purchaser; 5 . The power of a duly appointed agent, in certain cases, to sell chattels to an innocent purchaser, even after his factual authorization to sell has been revoked by the

${ }^{11}$ All legal rights, if genuine and valid, are really "concurrently legal and equitable," if considered with respect to the sanctions involved. See The Relations between Equity and Law (I9I3) II MICH. L. REv. 537; also Professor Walter Wheeler Cook, The Alienability of Choses in ActionA Reply to Professor Williston (I9I7) 30 Harv. L. REv. 449, 455.

" Compare Viscount Haldane, L. C., in Sinclair v. Brougham [1914] A. C. $398,418,419$, quoted ante, p. 732.

" Compare Lord Justice Cozens-Hardy in Capital \& Counties Bank, Ltd. v. Rhodes [1903] I Ch. 631, 655-656:

"The transfer by registered disposition takes effect by virtue of an overriding power, and mot by virtue of any estate in the registered proprietor. . . Notwithstanding that the land has become registered land, it may still be dealt with by deeds having the same operation and effect as they would have if the land were unregistered, subject only to the risk of the title being defeated . . . by the exercise of the statutory powers of disposition given to the registered proprietor, against which the mortgagee must protect himself by notice on the register." 
principal; 6. The power of a trustee to convey an unincumbered "legal title" to a bona fide purchaser for value without notice,the equitable rights, privileges, etc., of the cestui que trust being thereby extinguished.

The foregoing and others that might be mentioned are cases depending on the public policy of securing freedom of alienation and circulation of property in the business world. There may now be mentioned certain other cases dependent on somewhat different teleological considerations: I. The power of an ordinary agent (while his factual authorization continues) to divest the rights in rem, etc., of his principal and create new and corresponding rights, etc., in the agent's transferee; 2 . The power of a donee of a power of appointment to extinguish the rights in rem, etc., of the owner of a vested interest and to create new and corresponding rights, etc., in the transferee; 3. The power of the appropriate officer or officers to alienate property effectually in eminent domain proceedings; 4 . The power of a sheriff duly empowered by writ of execution to divest the rights in rem, etc., of the present owner of property and to vest new and corresponding rights, etc., in another; 5 . The power of a court, in a statutory proceeding to quiet title, to extinguish the rights in rem, etc., of the present owner and to give new and corresponding rights, etc., to the plaintiff; 6 . Various other powers of courts involving the "shifting" of title from one person to another.

In all these cases it is clear that the present owner has rights in rem, etc., in spite of his liabilities that they may be divested through the exercise of the various powers indicated.

Second: We must now consider a second form of the same general tendency to assume some rigid interdependence between the nature of a right in rem as such and the character of the proceeding available for its vindication. This erroneous assumption has most often been made in discussions of the question whether there are any instances of equitable rights in rem (multital rights), or, indeed, whether there could, in the very nature of things, be any instances of equitable rights in rem. Thus:

1877, Professor C. C. Langdell, Summary of Equity Pleading:

"The reason why all equitable rights to property are lost the moment the legal ownership is transferred for value to a person who has no notice that it is subject to 
any equitable rights, will be found in the fundamental nature of equitable jurisdiction, as explained in previous paragraphs. It is only by a figure of speech that a person who has not the legal title to property can be said to be the equitable owner of it. What is called equitable ownership or equitable title or an equitable estate is in truth only a personal claim against the real owner; for equity has no jurisdiction in rem, and cannot, therefore, confer a true ownership, except by its power over the person with whom the ownership resides, i. e., by compelling him to convey.",94

I900, Professor C. C. Langdell, Classification of Rights and Wrongs:

"Can equity then create such rights as it finds to be necessary for the purposes of justice? As equity wields only physical power, it seems to be impossible that it should actually create anything. It seems, moreover, to be impossible that there should be any other actual rights than such as are created by the State, $i$. e., legal rights. So, too, if equity could create actual rights, the existence of rights so created would have to be recognized by every court of justice within the State; and yet no other court than a court of equity will admit the existence of any right created by equity. It seems, therefore, that equitable rights exist only in contemplation of equity, i. e., that they are $a$ fiction invented by equity for the promotion of justice. Still, as in contemplation of equity such rights do exist, equity must reason upon them and deal with them as if they had an actual existence." ${ }^{\prime \prime 5}$

Circa 1886, Professor James Barr Ames, Lectures on Legal History:

"A trust, as every one knows, has been enforceable for centuries against any holder of the title except a purchaser for value without notice. But this exception shows that the cestui que trust, unlike the bailor, has not acquired a right in rem. ${ }^{952}$ This distinction is, of course, due to the fundamental difference between common-laze

* Summary of Equity Pleading (2d ed., r883) sec. 184.

( 1900 ) 13 HARv. L. REv. 673, 677. For analysis and criticism of the views of Professors Langdell, Ames, and Maitland as regards the relations of substantive equitable doctrines to substantive legal doctrines, see the writer's article, The Relations between Equity and Law (Igr3) II MrCH. L. REv. 537.

See also Supplemental Note on The Conflict of Equity and Law, post, pp. $767 \mathrm{ff}$.

$x_{n}$ For criticism of this assumption, see ante, p. 719, n. 22. 
and equity procedure. The common lawe acts in rem. The judgment in detinue is, accordingly, that the plaintiff recover the chattel, or its value. mon-law judges might have refused to allow the bailor to recover in detinue against a bona fide purchaser, as they did refuse it against a purchaser in market overt. But this would have involved a weighing of ethical considerations altogether foreign to the medieval mode of thought. Practically there was no middle ground between restricting the bailor to an action against his bailee, and giving him a right against any possessor. Equity, on the other hand, acts only in personam, never decreeing that a plaintiff recover a res, but that the defendant surrender what in justice he cannot keep."96

I904, Professor Frederic William Maitland, Trust and Corporation:

"I think it is better and safer to say with a great American teacher that 'Equity could not create rights in rem if it would, and would not if it could.' See Langdell, HaRVard Law Review, Vol. I, p. 60."

It is difficult to find solid foundation for such assumptions as the foregoing, or to understand how the notions connected therewith could have received such a large following. Are we forced to recognize that mere words-especially if they are Latin

But see Holmes, $J$. , in Tyler $v$. Court of Registration (I900) I75 Mass. 7r, 76 , quoted post, p. 760, n. 99.

${ }^{\infty}$ Lectures on Legal History (Igr3) p. 76. Compare Professor Harlan F. Stone, Law and its Administration (I915) pp. 93, 95: "Since a judgment at law affects only the property of the parties to the litigation, it is sometimes spoken of as a judgment in rem. The weakness, as well as the strength of such a system of procedure is apparent. To avail one's self of a legal remedy, one must wait until his rights have been interfered with and he has suffered some legal damage. . . .

"The distinguishing feature of equity is that the chancellor, or equity judge, who, because of his official position, originally had delegated to him the royal prerogative of command, has power to command things to be done or not to be done. That is, the equity courts act in personam, as it is said, or against the person, as distinguished from the law courts whose jurisdiction is in rem or over the property of the litigants. Thus, the chancellor could enjoin the defendant from committing a threatened injury to the plaintiff's property, or make a decree directing the defendant to convey property to the plaintiff in accordance with his contract. If the defendant failed to obey, he could be punished for contempt by imprisonment until he became obedient to the court."

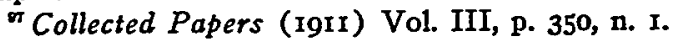


words-have such a surprisingly potent tendency to control thought?

Suppose, once again, that $A$ is owner of Blackacre, and that $B$ drives his automobile over A's lawn and shrubbery. A's primary right in rem is thereby violated, and a secondary right in personam arises in favor of A and against B,-an "obligatio," to use the term of Mr. Justice Holmes. ${ }^{98}$ A may sue B at law for damages and get, as a result of the "primary stage" of the proceeding, an ordinary legal judgment in personam for (say) $\$ 500$. Such judgment would "merge" or extinguish A's secondary right in personam together with B's secondary duty, and would create a (new) judgment obligation-right in personam and correlative duty-for the payment of $\$ 500$. Such judgment would be binding even though the judgment debtor, $B$, had no assets whatever. ${ }^{9 \theta}$ Thus, if B's judgment duty is not performed or discharged, a new action can, in most jurisdictions, be based thereon; though in some of the latter costs are denied to the plaintiff if the new action be brought without special reasons. ${ }^{100}$

But of course $A$ is not likely to wish merely an indefinite series of judgment obligations. If, therefore, $B$ has property either at the time judgment is rendered or at some later time, a "secondary stage"101 of the proceedings, beginning with a writ of execution, may be had. That is, the sheriff, under such a writ, has the power and the duty of selling sufficient property of $B$ and applying the proceeds to the satisfaction of the judgment. If the total proceedings culminate in this way, and only if they do so culminate, can we say that there has been a proceeding in rem, ${ }^{102}$

\footnotetext{
${ }^{9}$ See ante, p. 753.

" See Mr. Justice Holmes, in Tyler v. Court of Registration (1900) I75 Mass. 7I, 76:

"If the technical object of the suit is to establish a claim against some particular person, with a judgment which generally, in theory at least, binds his body . - . the action is in personam, although it may concern the right to a possession of a tangible thing."

See also a later passage in the learned judge's opinion (p. 77), referring to a judgment in personam as one establishing "an infinite personal liability."

${ }^{100}$ See Freeman, Judgments (4th ed., I898) sec. 432, ff.

${ }^{101}$ As regards "the primary stage" and "the secondary stage" of an action at law or suit in equity, compare Lord Hardwicke, in Penn. v. Lord Baltimore (I750) I Ves. 444, 454, quoted ante, p. 7I4, n. II.

${ }^{102}$ Even though such execution sale take place as a result of, and subsequently to, a judgment for money, neither the action brought to secure such
} 
or, more specifically, quasi in rem. ${ }^{103}$ That is to say, according

a judgment nor the judgment itself, is said to be in rem. (Cf., however, Professor Ames, ante, p. 758, and Professor Stone, ante, p. 759, n. 96.) On the contrary, both the action and the judgment are said to be in personam. See Mr. Justice Holmes, in Tyler v. Court of Registration (1900) 175 Mass. 7r, 76, quoted ante, p. 760, n. 99.

See also Mr. Justice Cutting, in Redington v. Frye (1857) $43 \mathrm{Me}$. 578,586 :

"And the embarrassment has arisen in a great measure by an erroneous idea that the remedy of the contractor and his sub-contractor is the same; whereas the former has his security on the goods and estate of his debtor, that is, in personam, as well as on the specific property benefited by his labor, which may be in rem, and after judgment it is optional with the creditor on which species of property he will levy his execution. . . But a sub-contractor has no claim against the owner of the property-his claim is only against the property (in rem), and the person and property of his employer (in personam).

It is believed, however, that it tends greatly to clarify matters to distinguish sharply, as already indicated, the two stages of the judicial proceedings; for the two taken together operate, as regards such property as is sold on execution, just as if such property had been attached $a b$ initio and subsequently sold, with no intermediate judgment in personam at all. Such an attachment proceeding would, of course, be called a proceeding in rem, or, more specifically, quasi in rem.

${ }^{103}$ Compare Mr. Justice Franklin, in Hook v. Hoffman (1915) I6 Ariz. 540, 557:

"While, properly speaking, actions or proceedings in rem are against the thing itself, and for the purpose of disposing thereof without reference to the title of particular claimants, the term has in a larger and broader sense been applied to certain actions and proceedings between parties, where the object is to reach and dispose of property owned by them or in which they have an interest; but, as these are not strictly in rem, they have frequently and more properly been termed quasi in rem, or in the nature of actions or proceedings in rem."

It is, of course, inaccurate to describe the proceeding strictly in rem as one which is "against the thing itself." See Mr. Justice Holmes, in Tyler v. Court of Registration (I900) I75 Mass. 71, 77:

"Personification and naming the res as defendant are mere symbols, not the essential matter. They are fictions, conveniently, expressing the nature of the process and the result, nothing more."

It is submitted, moreover, that the distinction between a proceeding strictly in rem and one quasi in rem is not correctly or adequately described by saying that the former is against all the world and the latter against only a particular person. When, e. g., a vessel is sold, in an admiralty proceeding strictly in rem, the effect is to extinguish the ownership (i. e., aggregate of rights, etc.) of the owner and to vest a new and corresponding ownership in the purchaser. So also, when a horse supposedly belonging to $B$, a judgment debtor, is sold by the sheriff under a writ of execution, a precisely similar result occurs, provided that $\mathrm{B}$, the particular 
to the meanings of the phrases in personam and in rem in this particular context, the proceedings from the beginning of the action down to and including the execution sale have a two-fold aspect and effect: (I) the primary stage of the entire proceedings, i. e., down to judgment, is, considered by itself, a proceeding in personam; (2) the primary stage and the secondary stage (from and after judgment) are, considered together, a proceeding quasi in rem with reference to the particular property sold in the execution sale.

Instead of suing $B$ for damages and receiving a judgment in personam, as above described, A might in some jurisdictions, in case $B$ be absent from the jurisdiction, attach a definite piece of B's property; and ultimately this might be sold to satisfy A's claim for damages. In this case the entire proceeding, since its only effect is to extinguish B's ownership of the very property attached (if any he had) and create new and corresponding ownership in the execution purchaser, is a proceeding quasi in rem.

It will thus be seen that, even in the lare courts the vindication of primary rights in rem may, according to the circumstances, be by procedings in personam, or by proceedings quasi in rem, or by both forms of proceeding (primary and secondary stages of the ordinary action at law). ${ }^{104}$ It is equally obvious that a primary right in personam, e. g., A's right that B pay him $\$ 10,000$, may frequently be vindicated only by an attachment proceeding,i. e., one quasi in rem.

judgment debtor named, actually does ozen the horse. The proceeding strictly in rem is sure to "hit the right target"; whereas the proceeding quasi in rem is not certain to do so.

The former, indeed, can be correctly and adequately understood only if it be realized that it is essentially an anonymous proceeding, being aimed to reach the interest of the true owner (or owners) of the property whoever he may be. The proceeding quasi in rem is, on the other hand, aimed to reach only the interest of a named party. The effect, therefore, so far as transfer of ownership is concerned, is necessarily conditional upon some legal interest being actually vested in the particular party named.

If effective, however, the ordinary proceeding quasi in rem, like that strictly in rem, affects the jural relations of all persons, not merely those of the present owner; for in each case the "transfer of title" involves, as regards all persons, the extinguishment of their duties to the present owner in respect to the particular object involved and the creation of new and corresponding duties to the new owner.

${ }^{204}$ Of course, even where a judgment in personam is sought, property may be attached $a b$ initio and subsequently sold to satisfy the judgment. 
The point that the primary rights may be in rem, although the vindication proceedings are in personam in the special sense that such phrase has in the present context, is often brought out in admiralty cases. Thus:

I907, Mr. Justice Holmes, in The Hamilton:

"We pass to the other branch of the first question: whether the state law, being valid, will be applied in the admiralty. Being valid, it created an obligatio, a personal liability of the owner of the Hamilton, to the claimants. Slater v. Mexican National R. R. Co., I94 U. S. x20, I26. This, of course, the admiralty would not disregard, but would respect the right when brought before it in any legitimate way. Ex parte $M c N e i l$, I3 Wall. 236, 243. It might not give a proceeding in rem, since the statute does not purport to create a lien. It might give a proceeding in personam." 105

Let us now suppose, in the Blackacre case, that instead of suing at law (after B has committed a destructive trespass), A secures from an equity court, $a b$ initio, an injunction against $B$. The decree of the court here (end of "primary stage" of the equitable proceeding) would result in imposing a (new) duty on $B$ not to trespass on Blackacre; and, correlatively, A would have a (new) equitable right. ${ }^{108}$ This first stage of the equitable proceeding would be in personam in the same general sense that the primary stage of the law court's is in personam. If $B$ fails to fulfil the negative duty imposed by the injunction, there will ordinarily occur a "secondary stage," resulting in imprisonment for contempt. So far as this is said to be "enforcement" or procedure in personam, it involves a different and more literal use of the phrase in personam than in any of the instances previously considered. ${ }^{107}$ But the point for special emphasis here is

${ }^{100}$ (I907) 207 U. S. 398, 405.

${ }^{100}$ Compare Fall v. Eastin (Igog) 215 U. S. I, 14-I5 (concurring opinion of Holmes, J.) ; Mallette v. Carpenter (1916) 160 N. W. (Wis.) 182 ; see extended comment in (1917) 26 Y ALE LAW Journal, 311.

See also The Relations between Equity and Law (I9r3) II MicH. L. REv. 537, 567-568.

${ }^{107}$ For a summary of the different uses of the pair of phrases, in personam and in rem, see ante, pp. 714-715.

For a comparison of imprisonment in an action at law, under a capias ad respondendum or capias ad satisfaciendum, with imprisonment for contempt in a chancery suit, for the purpose of coercing performance of 
that A's primary rights in rem are now being vindicated exclusively by equitable proceedings that are in personam in one sense so far as the primary stage is concerned and in personam in a different sense so far as the secondary stage is concerned.

On what possible ground, therefore, even assuming that equity could "act only in personam," 108 could it be said that for that reason there could be no equitable primary rights in rem, i. $\epsilon$, multital rights? If the usual legal proceedings were abolished, and A could vindicate his Blackacre rights in rem only in equity, would they thereby cease to be rights in rem and become only rights in personam?

Suppose, indeed, that we have a devise of Whiteacre to $\mathrm{X}$ for life, with remainder in fee to $Y$ if, and only if, $Y$ survives $Z$. Until Z's death before the death of $\mathrm{X}, \mathrm{Y}$ has, obviously, only a contingent remainder. Let us assume, further, that $T$ is threatening a destructive trespass to the premises, including the ruining of the mansion house. $Y$, the contingent remainderman, has no "legal" rights in rem, for he has no vested rights, etc., but only "possibilities"-i. e., potential rights, privileges, etc. ${ }^{100}$

Has he not, however, actual, exclusively equitable rights in rem, that is, respective multital rights against $T$ and other persons indiscriminately that they shall not seriously and permanently harm the estate? There are numerous decisions to the effect that $\mathrm{Y}$ has an exclusively equitable right that the life tenant, $\mathrm{X}$, shall

a decree, see the thorough discussion by Professor Walter Wheeler Cook, The Powers of Courts of Equity (Igr5) I5 CoL. L. REv. $108 \mathrm{ff}$.

See also The Relations between Equity and Law (I9I3) II Mrcr. L. REv. 537, 564-567.

${ }^{100}$ Such an assumption itself seems to be inaccurate and misleading in view of the power of a court of equity to issue writs of assistance and writs of sequestration. See Lord Hardwicke, in Penn v. Lord Baltimore (1750) I Ves. 444, 454, quoted ante, p. 714, n. II. The learned judge there refers to a proceeding under a writ of assistance as a means by which the "strict primary decree in personam" of a court of equity could sometimes be "enforced in rem."

Consider also the power of a court of equity to proceed in rem in mortgage foreclosure cases: extinguishment of the "equity of redemption." Cf. Paget v. Ede (1874) L. R. I8 Eq. rr8.

${ }^{100}$ This statement should, in strictness, be qualified.

Even at common law the contingent remainderman had the actual, or present, legal power to "release" his interest to the owner of the estate in possession. The power to devise, and the power to make a so-called "equitable assignment" should also be considered.

Very generally the contingent remainderman now has, as a result of statute, the present legal power to alienate his potential interest inter vivos. 
not commit "waste." It is clear, also, that the reasons are equally great for recognizing exclusively equitable rights against persons in general that they shall not harm the land and defeat the "legal" (i. e., concurrrently legal and equitable) rights, privileges, etc., of the remainderman if his estate should ever vest "in interest" and, ultimately, in "possession and enjoyment,"-that is, exclusively equitable multital rights, or rights in rem; and the dicta in the cases relating to waste afford strong support to this conclusion. ${ }^{110}$ Similarly, suppose that $J$ conveys the absolute legal title of Greenacre to $\mathrm{K}$ to secure a debt of $\$$ I0,000, the agreement being that $\mathrm{K}$ is to be entitled to possession until the maturity of the debt and that when the debt is paid $K$ is to reconvey the absolute legal title to $\mathrm{J}$. While $\mathrm{K}$ is thus in possession, $\mathrm{M}$ threatens to cut down the ornamental trees on the place. If the threatened acts were committed, $J$ would of course have no legal remedy, since the "legal" rights in rem, (i. e., rights concurrently legal and equitable) ${ }^{111}$ are now vested in $K$. It would, however, seem clear on principle that $\mathrm{J}$ is entitled to an injunction against $M_{\text {, }}{ }^{122}$ or, in other words, that $J$ has exclusively equitable multital rights, or rights in rem, relating directly to the physical corpus of

${ }^{100}$ Compare the following statements from judicial opinions :

Mr. Justice Battle, in Braswell v. Morehead (1852) 45 N. C. 26, 28:

"Owners of executory bequests, and other contingent interests, stand in a position, in this respect, similar to vested remaindermen, and have a similar right to the protective jurisdiction of the Court" (i. e., court of chancery).

Mr. Justice Connor, in Latham v. Roanoke, etc., Co. (1905) 5 I S. E. (N. C.) 780 :

"The interest of a contingent remainderman in the timber will be protected by a court of equity by injunction."

Mr. Justice Shaw, in Pavkovitch v. Southern Pacific R. Co. (1906) I50 Cal. 39, 50:

"The plaintiff's interest is not vested (Civ. Code, secs. 693, 695); and hence he has no present property in the rock removed, for the value of which damages can be computed, or to which he could have the right of present possession. . . But the rule is different with regard to the equitable remedy by injunction. The owner of a contingent interest may protect that interest against deterioration or destruction by enjoying a threatened waste."

I11 For the classification of jural relations as "concurrently legal and equitable" and "exclusively equitable," see The Relations Between Equity and Law (Igr3) II Micr. L. Rev. 537.

132 Smith \%. Collyer (1803) 8 Ves. 89, seems to have been such a case. The injunction was, to be sure, refused by Lord Eldon,-solely on the ground, however, that at that time bills to enjoin a "trespass" as distinguished from "waste" had not yet been definitely sanctioned by the 
the property. The nature of the equitable rights, privileges, powers, and immunities of the cestui que trust is too large a subject for adequate treatment in the present place; and so any further consideration of that interesting subject must be reserved for another occasion. ${ }^{113}$ It is hoped, however, that the various classes of rights and remedies already discussed are sufficient to show that the intrinsic nature of substantive primary rightswhether they be rights in rem or rights in personam-is not dependent on the character of the proceedings by which they may be vindicated. .14 $^{14}$

\section{WESLEY NEWCOMB HoHFELD}

YaIE UNIVERSITY, School of LAW.

court. Counsel for plaintiff argued: "The plaintiffs have no means of preventing or redressing this at law, the mortgagee having the legal title; and the mischief will be irremediable." Lord Eldon replied: "I do not recollect any instance of this sort. . . . It is not waste, but trespass by their own showing. There was no instance of an injunction in trespass till the case before Lord Thurlow upon a mine; to which I have alluded; which, though trespass, was very near waste. In that case, the first instance of granting an injunction in trespass, there was no dispute whatsoever about the right. Here the right is disputed."

See also Mr. Justice Brewer, in Wilson v. Rockwell (1886) 29 Fed. 674:

"The facts stated in the bill give complainants a clear right to a preliminary injunction. It is immaterial whether the legal title be in complainants or the Woodmass of Alston Company. The dispute between them does not concern trespassers. Both parties are in court, the company being made defendant. The full equitable title or ownership is with complainants, and a court of equity will protect the ozeners, as against trespassers, although the location of the legal title has not been finally determined."

In such a case as that relating to mortgagor and mortgagee, the situation is not fundamentally different from that of In re Nisbet $\mathcal{E}$ Potts Contract [1906] I Ch. 386-a case indicating that the equitable beneficiary of a restrictive agreement relating to land (sometimes called an "equitable easement") has rights even against wrongful possessors, or disseisors, of the "servient" land that they shall not act contrary to the terms of the restrictive agreement. In the latter case, as in that of the mortgagor and mortgagee, the legal owner of the land on which the acts of the defendant are done is not the equitable "agent" or "guardian" of the equitable beneficiary; and hence the grounds are peculiarly strong for giving to the equitable beneficiary direct equitable rights against all persons in respect to the physical corpus.

${ }^{123}$ See The Relations between Equity and Law (rgr3) Ir Mich. L. Rev. 537 , where the writer has sought to analyze most of the elements comprised in the interest of a cestui que trust.

See also Supplemental Note on the Conflict of Equity and Law, post, pp. 767 ff.

${ }^{114}$ Compare Bacon, Uses (Circa 1602) Rowe's ed., pp. 5-6; "So that usus E status, sive possessio, potius differunt secundum rationem fori, quam 


\section{SUPPLEMENTAL NOTE ON THE CONFLICT OF EQUITY AND LAW}

In the article on The Relations between Equity and Law (1913) II Mrch. L. Rev. 537 (see footnote II3, page 766) the present writer has sought to show that the interest of a cestui que trust constitutes a complex aggregate of exclusively equitable rights, privileges, powers, and immunities (some of these being in rem, or multital, and some of them in personam, or paucital); also that, in order to appreciate clearly the exact nature of all these jural elements it is necessary to consider definitely the "conflict" of the "legal" and the "equitable" relations involved and to discover the net residuum derived from a "fusion" of law and equity.

As implied by what has just been stated, the article above cited takes the position that while many substantive equitable rules are entirely consistent with legal rules, many other substantive equitable rules (i. e., those relating to the so-called "exclusive jurisdiction" and "auxiliary jurisdiction" of equity) are in conflict with so-called legal rules,-the latter being pro tanto "repealed," and rendered as invalid as scatutes that have been repealed by a subsequently enacted constitution.

It was, indeed, one of the purposes of the article to take strict issue with the thesis of such scholars as Professors Langdell, Ames, Maitland, and Stone (12 CoL. L. Rev. 756) that there is no conflict at all between substantive legal and equitable doctrines or, according to Maitland, only one or two possible instances of such conflict.

Professor Austin W. Scott, in a very recent article entitled The Nature of the Rights of the Cestui Que Trust (I9I7) I7 Cor. L. Rev. 269, 275, endorses, in part, the position of the present writer as set forth in the Mrchigan LAW REview, saying:

"Professor Ames has said that it is clearly inaccurate to say that the cestui que trust is the equitable owner of the trust property, because the trustee is the owner 'and, of course, two persons with adverse interests cannot be owners of the same thing.' Professor Maitland suggests that the cestui que trust cannot be regarded in equity as the owner of the trust property, because the law regards the trustee as the owner and it would be inconceivable chaos, 'civil war and utter anarchy', if law and equity should conflict. Now it is probably true that law and equity sometimes do conflict." (Italics are those of present writer.)

secundilm naturam rei, for that one of them is in court of law, the other in court of conscience."

Compare also Lord Dunedin, in Nocton v. Ashburton [1914] A. C. 932, 964:

"And then there are the duties which arise from a relationship without the intervention of contract in the ordinary sense of the term, such as the duties of a trustee to his cestui que trust or of a guardian to his ward. It is in this latter class of cases that equity has been peculiarly dominant, not, I take it, from any scientific distinction between the classes of duty existing and the breaches thereof, but simply because in certain cases where common justice demanded a remedy, the common law had none forthcoming, and the common law (though there is no harder lesson for the stranger jurist to learn) began with the remedy and ended with the right" 
But immediately after the sentence last quoted, Professor Scott says:

"But do they really conflict in this particular case? Is it not really the fact that both law and equity regard the trustee as the legal owner, and that both law and equity regard the cestui que trust as the equitable or beneficial owner? Of course the question who is equitable or beneficial owner is not generally one with which a court of law is concerned. But even in Bacon's day a court of law did sometimes concern itself with that question, and when it did it recognized that it was the cestui que trust who is the beneficial owner. (Bacon, Reading on Statute of Uses. * $y$ )"

No extended reply can be made here; but, with deference, it is submitted that the learned writer's position is untenable and that his reference to Bacon betrays a failure to understand the real nature of the analysis and argument relating to the "conflict" of equity and law.

The examples given by Bacon,-e. g., that "if cesty que use had resold his use unto the feoffee for six pounds, or contracted with a stranger for like sum, there is no doubt but it is a good condition or contract whereon to ground an action upon the case: for money for release of a suit in chancery is a good quid pro quo,"-instead of supporting Professor Scott's view, seem to sustain exactly the opposite conclusion. It is true enough that, in the purely collateral manner indicated by Bacon, even the court of law recognizes the equitable rights of the cestui que trust, and, as Professor Scott puts it, "regards the cestui que trust as the equitable or beneficial owner." But that purely collateral result necessarily means that the law court recognized: (I) that there was a "conflict" between the "legal rules" according to which the cestui had no rights or privileges and the equitable rules according to which the cestui had very substantial rights, privileges, etc.; and (2) that as to such "conflict" the equitable rules were, substantively considered, paramount and valid to the exclusion and "repeal" of the (preexisting) substantive (legal) rules. In other words, the law courts took a view in accordance with jural realism as distinguished from nominalism and fiction.

Let us go back to some period prior to $1400 \mathrm{~A}$. D. when equity had not yet recognized any interest in the cestui que use. C conveys Blackacre to $T$ with the agreement that $T$ shalr "hold" to the use of, or in trust for, $\mathrm{C}$.

(I) Under the common law, $T$ had the privileges of using and wasting the land, or in other words, had no duties to refrain from doing these things; and, correlatively, $C$ had no rights against $T$ that he should not use or waste the land. Let us assume now that a statute had been enacted providing, (a) that thereafter the trustee, instead of having the privilege of wasting the land, should be under a duty to the cestui not to waste it; (b) that such duty could be "enforced" by the cestui, not in the then existing courts of law, but in a new court specially created for the purpose. Would anyone doubt that the statute conflicted, substantively, with the common-law rules, and repealed them-even though, of course, if $C$ applied to the regular law courts for relief against $T$, it would be refused? In this matter we may well compare the many Workmen's Compensation Acts effecting important changes in the substantive law and at the same time establishing special tribunals (akin to the early courts of equity) for "enforcing" the law as thus modified. 
(2) Under the common-law rules of the early period referred to, C, the cestui que use, would have no privilege of entering on Blackacre, or actually using it, or in other words $C$ would be under a duty to stay off; and, correlatively, $\mathrm{T}$ would have a "legal" right that $\mathrm{C}$ should stay off. But let us assume that a statute is passed providing, (a) that a cestui should have the privileges of entering on the land and using it, that is, should have no duties to stay off, etc.; and (b) that if $T$ were to assert any supposed right against $C$ by suing in a regular court of law, the "defensive" remedy of C should consist, not in presenting some form of legal pleading, etc., to the ordinary court of law, but in securing from a new court specially created for the purpose an injunction against $T$ restraining him from continuing his action at law, etc.

Would anyone doubt that such statute conflicted substantively with the common-law rules and repealed the latter,-and that, too, even though the statutory rule was to be "enforced," or vindicated, in the roundabout (though practically effective) manner specially provided?

Finally, if, after these two statutes, the law courts took notice, in some purely collateral way such as that mentioned by Bacon, that $C$ had a substantial jural interest in Blackacre, would such recognition argue that there was no conflict between the substantive common-law rules and the substantive statutory rules; or would it mean exactly the opposite? These questions can be answered in only one way: and it would seem clear that the precise equivalents of these supposed statutory changes have been brought about by equitable repeals of substantive common-law doctrines,--with, however, this difference: that such repeals were covered and almost concealed by fictions! That is to say, the chancellor, from solid considerations of expediency, acted constantly under the fiction of not affecting the common-law doctrines at all: "Every jot and every tittle of the law was to be obeyed!" (Maitland actually believed that: Lect. on Eq. 17.) All of the "legal" rights, privileges, etc., of the trustee were to "continue" as before, but he was to "hold" them for the benefit of the cestui que trust. (For the use of the term "hold" as applied to trusts, see Maitland, Equity (I909) I7; Langdell (I887) I Harv. L. Rev. 59, 62; (I900) I3 Harv. L. Rev.; Ames (1887) I Harv. I. REv. 3, 9, II; Stone (1912) I2 CoL. L. REv. 756, Law and its Administration (Igr5) 96-97; A. W. Scott (I9I7) I7 Col. L. Rev. 275, 282, 290.)

Lord Mansfield has said that in legal matters nothing is so likely to mislead as a metaphor (see ante, p. 7II, n. 4); - and here the metaphor consists of "holding." One may literally "hold" a physical object for another person without the destruction or alteration of the object. But how is it when a trustee "holds" an aggregate of "legal" relations for the benefit of another?

How is it when a trustee "holds" a "legar" privilege of cutting ornamental trees with an "equitable" duty of not cutting ornamental trees?

Compare Lord Hardwicke in Robinson v. Litton (1744) 3 Atk. I83, I84:

"If the defendant has a legal right" [i. e., privilege], "and there "If the defendant has a legal to restrain him, I shall not do it. are no equitable circumstances to restrain he may hove a legal right" [i. e, privilege] "yet if there are equitable circumstances he may be restrained, and it is not 

proper for me to give a liberty" [i. e., privilege] "in doubtful
cases."

Compare also Lord Eldon, in Marquis of Devonshire v. Sandys (I80I)

6 Ves. 107, 109, Ir4:

"When this court took upon itself to depart from the rule of law as to waste, and interpose its restraining power, upon what is called equitable waste, beyond the rule of.law, one duty at least was imposed upon the Court; to define with precision and accuracy, in what cases the Court would interpose. . .

"This at least is clear; that Lady Sandys, claiming an estate for life without impeachment of waste, upon the deed in general, must be understood upon the deed to claim that estate with such powers as the law of the land, administered in a court of law, subject to such restraints to which that law is subject, as administered in a court of equity, gives her, as to felling timber; and neither party can allege surprise in finding their legal rights" [i. e., legal privileges] "affected by those restraints."

And what of a trustee "holding" a "legal right, or claim" that the cestui shall not cut ornamental trees, with, however, an "equitable no-right" in the trustee, or in other words "an equitable privilege" in the cestui? (See (I913) II MrcH. L. Rev. 537, 555, 569-571; Jones v. Tankerville [1909] 2 Ch. 440, 443, per Parker, J., now Lord Parker of Waddington; Hurst $v$. Picture Theatres, Ltd. [Igr5] I K. B. I; and comment (19I7) 26 YALE LAW JouRNaI, 395-399.)

In Jones v. Tankerville, supra, Lord Parker said:

"An injunction restraining the revocation of a license, when it is revocable at law, may in a sense be called relief by way of specific performance, but it is not specific performance in the sense of compelling the vendor to do anything. It merely prevents him from breaking his contract, and protects a right" [i. e., privilege] "in equity. which but for the absence of a seal would be a right at law, and since the Judicature Act it may well be doubted whether the absence of a seal in such a case can be relied on in arty court"

The fictions of the chancellor were not the less precisely such merely because the common-law judges generally acquiesced in the verbal pretense that all "legal relations" continued valid, as before. They realized, to be sure, what was happening (see Moyle, J., in Y. B. 4 Ed. IV (I464) fol. 7, p1. 9: "That cannot be in this court as I have told you, for the common law of the land varies in this case from the law of chancery," etc.); but the fiction was all the more convenient because the struggle for supremacy was not finally given up by the law judges until the prerogative decree of James I, 1616 A. D., in the struggle between Coke and Ellesmere.

It would now, however, seem time to recognize this venerable fiction as such, and to see through it to the ultimate jural realities. That much is demanded if we are to have exact and adequate analysis; and correct analysis, it must be remembered, is in this case, as in others, essential to the clear apprehension of the important teleological aspects of the various jural problems involved.

WESLEY NEWCOMB HOHFELD.

Yate Untversity, Schoor of Law. 